IZA DP No. 4318

Remittances to Latin America from Migrants in the United States: Assessing the Impact of Amnesty Programs

Catalina Amuedo-Dorantes

Francesca Mazzolari

July 2009 


\title{
Remittances to Latin America from Migrants in the United States: Assessing the Impact of Amnesty Programs
}

\author{
Catalina Amuedo-Dorantes \\ San Diego State University, \\ CReAM, FEDEA and IZA \\ Francesca Mazzolari \\ University of California, Irvine \\ and IZA
}

Discussion Paper No. 4318

July 2009

IZA

P.O. Box 7240

53072 Bonn

Germany
Phone: +49-228-3894-0
Fax: +49-228-3894-180
E-mail: iza@iza.org

\begin{abstract}
Any opinions expressed here are those of the author(s) and not those of IZA. Research published in this series may include views on policy, but the institute itself takes no institutional policy positions.

The Institute for the Study of Labor (IZA) in Bonn is a local and virtual international research center and a place of communication between science, politics and business. IZA is an independent nonprofit organization supported by Deutsche Post Foundation. The center is associated with the University of Bonn and offers a stimulating research environment through its international network, workshops and conferences, data service, project support, research visits and doctoral program. IZA engages in (i) original and internationally competitive research in all fields of labor economics, (ii) development of policy concepts, and (iii) dissemination of research results and concepts to the interested public.
\end{abstract}

IZA Discussion Papers often represent preliminary work and are circulated to encourage discussion. Citation of such a paper should account for its provisional character. A revised version may be available directly from the author. 


\section{ABSTRACT}

\section{Remittances to Latin America from Migrants in the United States: Assessing the Impact of Amnesty Programs*}

The magnitude of remittance flows to Latin America exceeds the combined inflows of foreign direct investment and official development assistance to the region. Since the United States is the destination country of the vast majority of migrants from Mexico, as well as from other Latin American countries, U.S. immigration policy can have a significant impact on the volume of remittances to the Latin American region. This paper studies how a generalized amnesty - a provision in the 1986 Immigration Reform and Control Act (IRCA), affected immigrants' remitting patterns. In models that control for immigrants' length of residence in the United States and for economic conditions in both the U.S. state of residence and the country of origin, we estimate substantial post-legalization drops in remittances sent home by Mexican-born migrants who legalized through IRCA. Given the potential positive impact of remittances on investment levels, entrepreneurship rates and the development of the financial sector, this finding underscores the importance of gaining a better understanding of the impact that immigration policies in immigrant-receiving countries may have on the stream of remittance flows to immigrant-sending communities in developing regions.

JEL Classification: F24, O15

Keywords: remittances, Latin American migrants, legal status, amnesty

Corresponding author:

Catalina Amuedo-Dorantes

Department of Economics

San Diego State University

5500 Campanile Drive

San Diego, CA 92182

USA

E-mail: camuedod@mail.sdsu.edu

\footnotetext{
${ }^{*}$ We are grateful to Marianne Bitler, Jan Brueckner, Daniel Chiquiar, Mireille Jacobson, Susan Pozo, and Steve Trejo for helpful suggestions. We also thank participants at the IUPLR second biennial conference, the 2007 Society of Labor Economists meetings, and the "Workers without Borders" conference organized by the Graduate School of Governance, Universiteit Maastricht for comments.
} 


\section{Introduction}

Remittances to the Latin American and Caribbean region have been increasing in size at dramatic rates - reaching \$68.1 billion in 2006 (Inter-American Development Bank, 2007). Mexico makes up a large share of the Latin American remittance market: as shown in Figure 1A, in 2006 remittances to Mexico reached $\$ 24.3$ billion. The magnitude of remittance flows to Latin America is impressive as it exceeds the combined inflows of foreign direct investment and official development assistance to the region. Not surprisingly, remittances have been regarded as an important source of external funding for fueling economic development (Taylor 1999) and, as some developing economies have grown accustomed to them, policy-makers have become increasingly worried about the potentially transitory versus permanent nature of international money transfers.

A variety of factors may affect the temporary versus long-lasting character of remittance flows, including changes in the composition and magnitude of migration flows, and changes in the characteristics of the existing migrant stock. Since the United States is the destination country of the vast majority of migrants from Mexico, as well as from other Latin American countries, U.S. immigration policy can have a significant impact on the volume of remittances to the Latin American region. While the remittance literature has paid close attention to the motivation, uses, and the micro and macroeconomic effects of these money flows in the receiving economies, the impact of U.S. immigration policies on migrants’ remitting patterns is an issue well understudied.

To start addressing this void in the literature, this paper provides an analysis of how legalization affects immigrants’ propensity to remit money back home. In particular, we study how the generalized amnesty granted as part of the 1986 Immigration Reform and Control Act (IRCA) affected immigrants’ remitting patterns. By improving their labor outcomes, legalization may increase immigrants' disposable income and their ability to remit to their families and communities back home. On the other hand, since the acquisition of legal permanent resident (LPR) status 
facilitates family reunification, a generalized amnesty may curtail migrants' remitting incentives. The acquisition of LPR status might also affect remittances by changing immigrants' perceived degree of uncertainty regarding their migration experience. Specifically, it may lower the propensity to remit of migrants that did so for insurance purposes. As such, the impact of an amnesty on immigrants' remitting behavior is a question that needs to be assessed empirically.

As shown in Figure 1B, at the time of IRCA implementation there is no detectable drop in the total volume of remittances sent to Mexico by Mexican-born individuals working in another country. Macroeconomic data, however, may be affected by a series of confounding factors - such as new emigration flows from Mexico. ${ }^{1}$ In addition, aggregate data are not apt for detecting, as we aim to, changes in the remitting patterns among the subset of individuals affected by IRCA's general amnesty, that is, long-term migrants. To do so, in this paper we use the only available micro data that are suitable for this purpose, that is, the Legalized Population Survey (LPS)—a nationally representative sample of undocumented immigrants who benefited from IRCA's amnesty program. Specifically, we estimate changes in remitting patterns between 1987 (before migrants acquired LPR status) and 1991 (after they did). In models that control for immigrants’ length of residence in the United States as well as for economic conditions in both the U.S. state of residence and the country of origin (as a way to capture business cycle effects affecting, respectively, an immigrant’s capacity to remit and her motives to do so), we estimate a post-legalization drop of 8 percentage points in the likelihood that Mexican-born immigrants remitted money home and a 29 percent drop

\footnotetext{
${ }^{1}$ Between 1986 and 1995, 2.8 million immigrants from Mexico were admitted to the United States as LPR -of which "only" around a million were pre-1982 entrants who adjusted their status through the amnesty (INS, 1996 Statistical Yearbook). Estimates of inflows of undocumented population support the notion that also illegal immigration, much of which seem to have originated from Mexico, steadily increased over the same period (Office for Policy and Planning 2003). Large immigrant inflows, coupled with the well-documented higher propensity to remit of recent immigrants (Menjivar et al. 1998, Amuedo-Dorantes and Pozo 2006, Orozco et al. 2005), are likely to have caused increases in the volumes of remittances that may dwarf any drop among the population of long-term migrants who legalized through IRCA. In addition, some of the growth in remittances observed in aggregate data may be the by-product of improvements on the part of banks and other institutions in tracking remittance flows (Cañas et al. 2007).
} 
in the dollar amount remitted. In contrast, post-legalization changes in the remitting patterns of other Latin American immigrants are not statistically different from zero once we account for the time spent in the United States, which suggests that, for this group, assimilation may explain most of the observed remittance decay over time. There are several issues in interpreting the estimation results as conclusive evidence that legalization did cause a drop in remittances among Mexicans. We present a number of robustness checks and indirect tests addressing these issues. Overall, our analyses suggest that none of them is likely to drive our findings.

The present study addresses a policy question that is increasingly important in the light of recent bipartisan discussions in the U.S. Congress on a comprehensive immigration bill that would allow legalization for a large fraction of the undocumented population residing in the United States - a population recently estimated at around 12 million (Passel 2006). Although an amnesty is of first-order benefit to migrants themselves and to their families, our results suggest that it may negatively affect the stability and volume of remittance flows to the local communities where immigrants originate. The decrease in remittances may, in turn, halt the development prospects of these communities since remittances, despite being primarily private transfers within families, have also positive spillover effects on local economies. For example, as shown by the literature studying consumption smoothing in low-income economies, a cash injection into a group of households may affect other families living in the same village by increasing informal loans and transfers from family and friends (Rosenzweig 1988a and 1988b; Udry 1994; Townsend 1995; Fafchamps and Lund 2003; Angelucci and De Giorgi 2009). Thus, it is important to gain a better understanding of the impact that immigration policies in immigrant-receiving countries may have on the stream of remittance flows to developing regions to help design interventions that mitigate the potentially negative effects (e.g. on entrepreneurship rates and on the credit market) of foreseen drops in remittances. 


\section{Literature Review and Conceptual Framework}

\section{A) Motives for Remitting}

Altruism is one of the key motives for remitting money home (Becker 1974, Stark 1991). If migrants remit altruistically, remittances should vary with migrants' remitting capacity and the needs of friends and family back home. Another reason for remitting money back home is to make a specific purchase or investment (e.g., setting up a small business). This is particularly common among temporary migrants who migrate for the specific purpose of accumulating assets for future retirement (Ahlburg and Brown 1998, Glytsos 1997). A third motive for remitting contemplated in the literature is insurance. Because migration is fraught with uncertainties, migrants may cover for these risks by remitting funds home - as a way to maintain a "good standing” with relatives in the home country and secure a place within the family in the event of an unsuccessful migration experience (Lucas and Stark 1985, Amuedo-Dorantes and Pozo 2006).

Depending on migrants’ remitting motives, we may expect legalization to affect remittance flows differently. If migrants remit for altruistic or saving/investment purposes, legalization may result in larger remittance flows to the extent that the acquisition of LPR status is associated with higher earnings (Kossoudji and Cobb-Clark 2002, Kaushal 2006). However, since legalization facilitates family reunification, remittances may drop. Likewise, remittances may decrease if they are mainly sent for insurance purposes, since legalization reduces deportation risks and might lessen income uncertainty by opening up new job opportunities.

\section{B) Usages and Effects of Remittances}

The literature on how remittances are used and on their potential impacts at the household, local and country level has grown significantly over the past two decades. Most empirical analyses find that remittances are primarily used to finance day-to-day consumption needs, such as food, 
clothing and shelter. An increasing number of studies, however, also document that remittances boost access to education and health services among recipient households (e.g. Kanaiaupuni and Donato 1999, Cox-Edwards and Ureta 2003, Hanson and Woodruff 2003, Amuedo-Dorantes et al. 2007, Yang 2008). There is also mounting evidence of a positive impact of remittances on productive investments. For example, Durand et al. (1996) document that 10 percent of migrants returning from the United States to Mexico in the 1980s-early 1990's spent at least some of their repatriated earnings productively. More recently, Woodruff and Zenteno (2007) have analyzed access to remittance flows among small-scale entrepreneurs in urban Mexico and found that migration networks are associated with higher investment levels. Remittances have also been shown to promote entrepreneurship and business start-ups. Massey and Parrado (1998) examine enterprise formation in a sample of 30 communities in central-west Mexico, and conclude that earnings from working in the United States provided an important source of start-up capital in 21 percent of new business formation. ${ }^{2}$

In addition to the growing research on the impact of migration and remittances on sending country development, there is also increasing evidence on their importance in alleviating credit constraints. In favor of this notion, the connection between migration networks and investments documented in Woodruff and Zenteno (2007) is found to be stronger in high-capital sectors. A recent literature has also noted that remittances can be credited with the development of the financial sector (e.g. Aggarwal et al. 2006).

Finally, remittances have been acknowledged as sources of foreign exchange and macroeconomic stability. For example, they have been associated with a reduced likelihood of current

\footnotetext{
${ }^{2}$ Besides Mexico, there is also evidence on remittances being used for productive investments in a variety of other countries. For example, using the Asian currency crisis as a source of changes in the value of remittances received by Filipino families with migrants overseas, Yang (2008) finds that positive remittance shocks lead to enhanced entrepreneurship, with recipient households working more hours in self-employment, and becoming more likely to start relatively capital-intensive household enterprises.
} 
account reversals (Edwards 2004, Milesi-Ferretti and Razin 1998, 2000) and they have been found to rise when the recipient economy suffers financial crises, natural disasters, or political conflicts (Ratha 2006).

In sum, there is a large literature (and growing empirical evidence) on the role that remittances play in shaping welfare and economic activity in migrant-sending countries, raising the concern that a drop in these cash injections -such as the one that may follow immigrants' legalization - would have negative effects on the economic development of immigrant-sending communities.

\section{The 1986 Immigration Reform and Control Act}

Enacted in 1986, IRCA granted amnesty to around 1.6 million long-term (“pre-1982”) undocumented immigrants. ${ }^{3}$ The amnesty program consisted of two phases. First, undocumented migrants had to apply for adjustment of status, and provide proof of continuous residence in the United States since January 1, 1982. To do so, migrants were allowed to use a variety of documents, such as a driver's license, bank statements, or gas, electric and other bills. Filing fees were approximately \$185 (Cooper and O’Neil 2005), but poor families were eligible for fee waivers. After obtaining temporary legal status, migrants were given an additional 18 months to prepare their application for LPR status (i.e., for obtaining a "green card”). In this phase, they had to prove "basic citizenship skills", such as a minimal understanding of English and of U.S. history and government. Once permanent status was granted, the immigrant could sponsor a spouse or children for permanent residency.

When first signed into law on November 6, 1986, few individuals understood the legalization program and its requirements, which may explain why the process took some time to

\footnotetext{
${ }^{3}$ In addition, around 1.1 million individuals who demonstrated 60 days of seasonal agricultural work between May 1985 and May 1986 legalized through the Special Agriculture Worker (SAW) Program.
} 
take off. However, as the first group of applicants received their temporary residence cards, others who qualified started to apply. INS established 107 offices and worked with hundreds of local voluntary agencies and community organizations that helped process applications throughout the United States. It is estimated that most undocumented migrants applied for legalization (Warren 1995, Hagan 1994, Hoefer 1991). The process of legalization lasted an average of two years -more than 95 percent of legalizations took place between 1989 and 1991, and had a remarkably high approval rate -about 9 out of 10 applicants obtained LPR status (Rytina 2002).

\section{Data}

To assess the impact of legalization on remittance patterns, this study analyzes data from the Legalized Population Survey (LPS) -a nationally representative sample of the population that legalized through IRCA's general amnesty program. ${ }^{4}$ The LPS is a two-wave survey. The universe for the first wave (LPS1) was the population of adult legalization applicants. Interviews took place in 1989, and collected information from 6,193 individuals who had applied for temporary residence status by January 31, 1989. In the first wave, respondents were asked about the dollar amount sent to family and friends in other countries during 1987. In the follow-up survey (LPS2), conducted in 1992, about 4,012 LPS1 respondents who were granted legal permanent residence by January 1992 were re-interviewed and asked about the dollar amount sent to family and friends during $1991 .^{5}$

As usual with panel data, a sample selection problem would arise if the probability of dropping out from the sample were systematically related to the outcome of interest. We test for sample selection bias by specifying a model for remittances that (i) is estimated for all respondents in LPS1, and (ii) includes an indicator variable that takes on the value one for respondents that are

\footnotetext{
${ }^{4}$ The SAW population was not surveyed.

${ }^{5}$ As shown in Appendix Table A1, the universe for the follow-up survey excluded 1,193 individuals who were either randomly selected for exclusion because of resource limitations (691 individuals), or were found to be ineligible by January 1992 (502 individuals, most of which were still waiting for a decision). Of the remaining 5,000 individuals sampled for the LPS2, there were 890 non-respondents and 98 individuals who were later found ineligible.
} 
also in LPS2. The coefficient on this "selection indicator" is found not to be statistically different from zero. This suggests that sample selection should not be an issue in our analysis. The results reported in the paper are obtained from restricting the sample to respondents in both waves. ${ }^{6}$

Migrants born in Mexico represent 69 percent of the legalized population surveyed in the LPS balanced panel, and other Latin Americans represent another 24 percent. Since small sample sizes hinder the possibility to run multivariate analyses for other origin groups, in this study we restrict the analysis to individuals born in Mexico or in other Latin American countries.

\section{Research Strategy}

The goal of this paper is to assess whether legalization affects the remittance behavior of undocumented immigrants who obtain LPR status. Under current U.S. immigration laws, there are thousands of undocumented migrants who obtain LPR status every year. For example, in 2000, out of the 450 thousand immigrants that adjusted their status to permanent legal residents, about 6 percent had entered the country "without inspection” (INS, 2000 Statistical Yearbook). The share of undocumented at the time of adjustment might have been even larger, since some might have overstayed their visas.

A simple comparison of the remittance behavior of undocumented and legalized immigrants at a point in time would not be informative of the effects of changes in their legal status, as some of the differences between the two groups might be due to unobservable characteristics of migrants who successfully applied for adjustment of status. The relationship between remittances and legalization should instead be modeled by an equation such as the following:

$$
R_{i t}=\alpha_{1} \text { Legalized }_{i t}+\alpha_{2} \text { Years } U S_{i t}+\alpha_{3} X_{i t}+\gamma_{t}+c_{i}+\eta_{i t}
$$

\footnotetext{
${ }^{6}$ Consistent with sample selection not being an issue, estimation is robust to running the analysis on the unbalanced panel (results are available from the authors upon request).
} 
where $R_{i t}$ is a measure of remittances sent by individual $i$ in year $t$; Legalized $_{i t}$ is an indicator variable that takes on the value one if the foreign-born person is a legal permanent resident in year $t$; Years $U S_{i t}$ measures length of residence in the United States; and $X_{i t}$ is a vector of other timevarying individual characteristics that might affect one's remittance behavior. Finally, $\gamma_{t}$ is a time fixed effect, $c_{i}$ is an individual fixed effect and $\eta_{i t}$ is an idiosyncratic shock.

Inclusion of the individual effect $c_{i}$ in equation (1) is meant to address the self-selection bias arising from the fact that individuals choose to apply for legalization -a choice that could be correlated with time-invariant unobservable characteristics also affecting their remitting behavior. A fixed-effects (FE) estimator of $\alpha_{1}$ would then arguably capture the impact of legalization on remittances. Unfortunately, estimation of equation (1) would require data that are not available, that is, longitudinal data on undocumented immigrants who may or may not adjust their status.

Self-selection bias, however, can be ruled out in the case of a program that either randomly or universally assigns legal status. If self-selection is not an issue, the inclusion of individual fixed effects is not needed. We argue that self-selection, if any, is a second-order concern in the case of IRCA, since the amnesty was close to a universal program. First, the take-up rate of IRCA's amnesty program is estimated to have been very large, between 75 and 100 percent: three million persons applied for legalization at a time when estimates of the illegal immigrant population residing in the United States ranged between 3 and 5 million (Hoefer 1991). Second, there is no clear reason to expect the incomplete take-up rate (if any) to be systematically related to unobservable personal characteristics that also affect remittance behavior. The administrative filing costs should not have disproportionally deterred low-income people from applying for amnesty because poor families were eligible for fee waivers. The other key requirement for obtaining general amnesty was the ability to prove continuous residence in the United States since 1982. 
However, given that a large variety of documents were accepted for that purpose, this requirement should not have significantly affected the composition of the pool of eligible applicants.

Therefore, assuming a negligible selectivity bias, we can estimate whether IRCA affected remittance patterns of undocumented immigrants by studying the 1987-1991 change in the propensity to remit among the LPS respondents. The main concern with a before-after estimate is that it will capture not only the effects of legalization, but also of any other time-varying factor contemporaneous with IRCA that might have affected migrants' remittance behavior. First of all, the simple fact that four years elapsed between 1987 and 1991 might have resulted in remittance decay because of immigrants' "assimilation" to the host country. We can address this first concern by estimating the following regression model by pooled Ordinary Least Squares (OLS):

$$
R_{i t}=\beta_{0}+\beta_{1}{\text { Years } U S_{i t}}+\beta_{2} X_{i t}+\gamma_{1991}+\varepsilon_{i t}, \quad t=1987,1991
$$

where $\gamma_{1991}$ is a dummy that takes the value one if the observation comes from the second wave, and zero otherwise. It must be noted that, as opposed to equation (1), equation (2) places the individual effect $c_{i}$ in the error term. Otherwise, the "assimilation" effect would not be separately identified because of perfect multicollinearity between $\gamma_{1991}$, the linear term YearsUS $S_{i t}$ and $c_{i}$-which would absorb the effect of any time-invariant characteristics, such as year of entry in the United States. ${ }^{7}$ In practice, in a pooled OLS estimation the same individual provides two separate observations (one for each time period). Since the composite error in (2), $\varepsilon_{i t}=\left(c_{i}+\eta_{i t}\right)$, is serially correlated because of repeated observations for the same individual, in the regression analysis standard errors are clustered at the individual level. ${ }^{8}$

\footnotetext{
${ }^{7}$ Even if we refer to $\beta_{1}$ as capturing the effects of a migrant's assimilation to the host country over time, this parameter may also reflect cohort-of-entry effects (Borjas, 1985). Unfortunately, with only two-years of data, the two effects cannot be separately identified.

${ }^{8}$ In addition to pooled OLS with cluster-robust variance estimation, we have also used random-effects (RE) inference and found no discernable differences between the two methods. Consequently, since RE estimation imposes more assumptions on the error term than pooled OLS, we present results for the latter.
} 
Even if the estimated $\gamma_{1991}$ in (2) represents the average change in remittances once the effects of years of residence in the United States have been accounted for, there remains the concern that changing economic conditions in either the United States or a migrant's country of origin might explain some of the 1987-1991 change in remittances. For example, if the weak U.S. labor market in the early 1990's worsened migrants' work opportunities and their earnings, then remittances would have dropped in 1991 even in the absence of legalization. Ideally, we would remove the business cycle aspects of the change in remittances by differencing out from a comparison group composed by a randomly selected group of undocumented immigrants, similar to the target group, but ineligible for, or unaffected by, amnesty. However, the programmatic features of IRCA make it virtually impossible to identify such a group. Additionally, there is no other longitudinal dataset collecting information on migrants' remittances and legal status over the period that is relevant for our analysis. ${ }^{9}$

Even if data limitations prevent us from identifying the effects of legalization on remittances using a difference-in-difference approach, information on LPS respondents’ U.S. state of residence and country of origin allows us to control for the effects of the business cycle by exploiting its geographical variation. Specifically, we expand the estimating equation to include time-varying economic indicators for a migrant's U.S. state of residence $\left(E_{s t}\right)$ and country of origin $\left(E_{c t}\right)$ :

$$
R_{i s c t}=\beta_{0}+\beta_{1} \text { YearsUS }_{i t}+\beta_{2} X_{i t}+\beta_{3} E_{s t}+\beta_{4} E_{c t}+\gamma_{1991}+\gamma_{s}+\gamma_{c}+\varepsilon_{i s c t}
$$

where $\gamma_{s}$ and $\gamma_{c}$ are respectively state-of-residence and country-of-origin fixed effects.

\footnotetext{
${ }^{9}$ For the case of Mexico, we have explored the possibility of using data from the Mexican Migration Project (MMP), a household survey of several rural and migrant-sending Mexican communities. However, the MMP is not suitable for our analysis because of its focus on return migrants (rather than migrants currently residing in the United States). Additionally, when focusing on a particular year and on undocumented migrants, sample sizes are very small.
} 


\section{Stylized Facts}

Table 1 reports average values of relevant variables in each of the two LPS surveys, calculated for all immigrants as well as separately for immigrants from Mexico and other Latin American countries. In 1987, sixty-six percent of respondents remitted home an average of $\$ 2,100$. $^{10}$ By 1991, there was a reduction in both the percentage of individuals who remitted and the average dollar amount sent. The former dropped to 55 percent and the latter to approximately $\$ 1,610$. A comparison of the remittance behavior of Mexicans and other Latin Americans shows that Mexicans were somewhat less likely to remit in 1987 but, if they did, they sent back home slightly larger amounts. In both groups, however, the propensity to remit as well as the amounts remitted significantly dropped between 1987 and 1991.

The observed drops are consistent with legalization negatively affecting migrants' propensity to remit, but may also arise from assimilation effects or from changing economic conditions. Fortunately for identification purposes, there is some significant variation in the economic performance of U.S. states and of migrants' countries of origin. For example, between 1987 and 1991, the unemployment rate increased in California, but was stable in Illinois and decreased in Texas. Additionally, country economic conditions greatly differed across the Latin American region. The Mexican economy -at the time largely dependent on oil revenues- was the most badly hit by the 1986 fall in world oil prices, with GDP per capita falling by 5.7 percent that year and by another 0.15 percent in 1987. In contrast, 1990 and 1991 were years of recovery, with per capita growth rates of 3.1 and 2.3 percent respectively. Other Latin American countries had different experiences. For instance, El Salvador and Guatemala were hit by milder shocks in the mid 1980s and experienced more stable macroeconomic conditions over the sample period under consideration. Furthermore, while Colombia enjoyed sustained growth, in Argentina and Brazil

\footnotetext{
${ }^{10}$ Amounts sent home are in 1991 dollars.
} 
GDP per capita fell sharply in 1989 and 1990 respectively - that is, later than in Mexico. Equation (3) aims at disentangling the effects of legalization from the effects of the economy by exploiting these differences in the macroeconomic performance of LPS respondents' economies of residence and of origin.

Besides remittances and economic indicators, Table 1 also reports average values for those migrants' socio-demographic characteristics that are controlled for in the regression analyses. Fiftyfive percent of LPS respondents are men. In 1987, respondents are on average 32 years old and have been in the United States for about 10 years. Additionally, about 83 percent of them were undocumented when they last entered the country. Only a negligible number of respondents are observed to either acquire more education or to change state of residence between the two waves, and, therefore, average values for these variables are remarkably stable across waves. ${ }^{11}$ In both surveys, around 78 percent of respondents do not have a high-school degree, 61 percent reside in California, fourteen percent in Texas, and another 17 percent in New Jersey, New York, Illinois or Florida.

Table 1 also lists economic and family composition variables. Since these variables may be affected by legalization, they are excluded from the estimated equation. In line with worsening macroeconomic conditions, respondents’ employment rate decreases from 80 to 77 percent between waves. On the contrary, a larger fraction of households report incomes over $\$ 30,000$ by 1991 . This fact, though, is not necessarily indicative of real income improvements, since income variables are not deflated. ${ }^{12}$

With respect to migrants' marital status, the fraction of respondents with spouses abroad is very low and remarkably stable over time (around 4 percent in both waves), while the percentage of

\footnotetext{
${ }^{11}$ Efforts to relocate respondents in wave 2 focused in states of residence in 1989, so that out-of-state migrants are likely to be underrepresented.

${ }^{12}$ Information on family income is reported in brackets that are the same in both waves.
} 
respondents with spouses in the United States increases from 61 to 71 percent. The first fact seems to undermine the importance of family reunification in explaining remittance drops, but the second suggests that new family responsibilities might be a relevant factor. Rather than representing new family formation, the increasing number of spouses living in the United States in LPS2 might as well partly reflect a response to legality. Specifically, given the uncertainties surrounding the legalization process at the time IRCA was passed, some respondents in LPS1 could have been reluctant to report an undocumented spouse, especially one who did not make the 1982 cutoff.

Before presenting the results of the regression analyses, in what follows we discuss a series of concerns related to the data and to our proposed research strategy.

\section{A) Anticipation Effects and the Role of Family Reunification}

The identification strategy proposed in this paper compares migrants' remitting behavior in 1987 and 1991, that is, before and after migrants acquired LPR status. Since IRCA was passed in 1986, however, both points in time are after the legalization program was known to migrants. Indeed, some of them had already applied for temporary legal status in 1987. If in 1987 migrants already expected to get LPR status, anticipation effects could bias a before-after estimator. For example, knowing that they were likely to be legalized in the near future, migrants may had already cut back on remittances in 1987 and refocused their investments in the United States. This would bias our estimate against finding a negative effect of legalization. On the other hand, if they expected to get LPR status and to be able to sponsor relatives into the United States, migrants might have been sending money back to their families in 1987 to help them prepare for the move. Remittances in 1987 would have then been larger than in a normal year, and, to the extent that the family reunited by 1991, this would bias our estimate towards finding a negative effect of legalization. 
To indirectly assess the extent of anticipation effects, Table 2 groups respondents based on the expected strength of these effects and compares changes in remittances across different groups. First, we would expect anticipation effects to be stronger for early applicants. Yet, drops are not statistically different for those who applied for temporary resident status in 1987 (56 percent of LPS respondents) and those who waited until 1988. Second, we compare remittance changes for LPS respondents that are more or less likely to have reunified with their families. First, we split the sample according to respondents' likelihood to have reunified with a spouse or partner. Not surprisingly, respondents whose spouse moved to the United States experienced the most dramatic drop in remittances (panel C). We cannot assess whether or not this drop is due to remittances being unprecedentedly high in 1987 because of the need to finance the spouse's move. Even so, since respondents who reunited with their spouses only represent 2 percent of the balanced panel, this group is not likely to drive the estimation results. Rather than reunifying with their spouses, respondents might have reunified with their partners. This might be the case for some of those who were not married at the time of the first survey, but had a partner or spouse living in the United States by the time of the second survey (panel D, 13.6 percent of the sample). However, the change in remittances for this group is not statistically different from the average change in the full sample. Moreover, remittance decay is also large for those who did not reunite with a spouse or partner, either because they were not living with a partner throughout the sample period (panel E) or because the spouse was already living in the United States at the time of the first survey (panel F). Finally, against the notion that drops in remittances are specific to those who reunified with their families, even respondents with spouses abroad in both periods (panel G) are found to experience remittance drops that are not significantly different from the average drop. ${ }^{13}$

\footnotetext{
${ }^{13}$ If we could interpret these figures as capturing the effects of legalization, drops in remittances for migrants who did not experience family reunification would be consistent with the higher probability of staying in the United States of
} 
We focus next on comparing remittance changes for respondents who are more or less likely to have reunified with their children. Both waves collect information on the number and ages of own children living with the respondent. LPS2 also asks whether household members where already living in the same household at the time of LPS1. As such, we can identify respondents who are likely to have brought children to the United States (panel H), as well as those who should not have done so since they had no children older than four living with them at the time of LPS2 (panel I, 28 percent of the sample). The first group did experience larger than average drops in remittances, but it only represents 9 percent of the sample. Also, against the notion that family reunification (and so, the potential bias from financing it) is the driving force for the observed drops, remittance decay in the group without young kids does not significantly differ from the average drop in the rest of the sample, who may or may not have reunified with other relatives.

Overall, the figures in Table 2 suggest that: (i) even if remittance drops are the largest among those respondents who did bring their spouse or children to the United States, they are also present and large among groups who are less likely to have experienced family reunification; and (ii) family reunification does not appear to have involved a substantial fraction of the sample. The first finding undermines the possibility that the observed drops in remittances are simply explained by migrants financing the move of relatives at the time of the first survey. Both findings show that, besides family reunification, other factors must be driving the observed remittance decay.

\section{B) Recall Bias}

The information on remittances sent home in 1987 and 1991 is collected respectively in 1989 and 1992. As such, there may be two kinds of concerns. First, variables might be measured

newly legalized migrants -- which could weaken investment and insurance remitting purposes. However, the figures in Table 2 represent unconditional average remitting rates. Hence, we cannot yet make a claim regarding the extent to which the observed changes can be attributed to legalization. The regression framework will allow us to do so after controlling for other time-varying factors that may affect remittances. 
with error because of recollection problems. Second, respondents may be erroneously answering questions as if they referred to the survey date (Sudman and Bradburn, 1973). With regard to the first issue, our estimates would be biased if the recall error changed between the two surveyssomething we might worry about given that recall may differ over one year compared to two years. However, since interviews for LPS1 took place between February and June of 1989, and for LPS2 between April and September of 1992, the difference in the recollection period is indeed as low as 5 months when comparing those interviewed early in LPS1 and late in LPS2. ${ }^{14}$

While we cannot sign the bias that may arise from recall error, if respondents tend to report current rather than past amounts, our approach would be biased against finding a negative effect of legalization. In fact, instead of a before-after estimate (the 1987-1991 change), we would be calculating the change between 1989 and 1992 - that is, two points in time after legalization. Hence, even if legalization did cause remittances to drop, we would be less likely to capture it.

\section{C) Changes in Remitting Behavior}

Table 3 is a transition matrix that documents changes in individual remitting patterns and can be used to assess the extent to which average remittance drops across waves are explained by changes in migrants' behavior. Twenty-nine percent of migrants changed their remitting behavior at the extensive margin and more than two-thirds of them were "quitters" who remitted only in the first period. In particular, the eleven percentage-point drop in the average propensity to remit between waves arises from the fact that the share of the legalized population that stopped remitting (20 percent) is larger than the share that started remitting (9 percent).

A perusal of the characteristics of the "new remitters" reveals that, as opposed to other groups, they experienced employment gains and a sizable increase in post-secondary education after

\footnotetext{
${ }^{14}$ Unfortunately, the month of the interview is not disclosed, so that we cannot test whether our estimates are robust to restricting the sample in a way that reduces differences in the recollection period across waves.
} 
legalization. In addition, this is the group with the largest family income growth. ${ }^{15}$ New remitters stand out as the group for whom legalization may have boosted remitting capacity and, as such, remittances sent either for altruistic or investment purposes. Quitters, instead, are those more likely to have reunified with their spouses as well as with their children. In both cases, however, continuous remitters are similar to quitters, ${ }^{16}$ suggesting that family reunification had heterogeneous effects. In addition, employment rates among "quitters” dropped from 82 to 66 percent -which suggests that controlling for economic conditions in local labor markets (as we do in the regression framework) is crucial to disentangle the potential impact of legalization from the confounding effects of the business cycle.

Table 3 also reports the average amounts remitted by different groups, allowing us to study changes in the remitting behavior at the intensive margin. Since the average amounts sent in 1987 by "quitters" were larger than the amounts sent in 1991 by new remitters, some of the drop in average remittances across waves is explained by compositional changes. However, almost half of the legalized population remitted in both periods and their average amount remitted significantly dropped. Therefore, changes in the amounts remitted are not merely explained by compositional shifts, but also by changes in the behavior of those remitting in both periods.

\section{Estimation Results}

Tables 4 and 5 display the results from estimating variants of equations (2) and (3) on a balanced panel of LPS respondents from Latin America. The dependent variable is, respectively, an indicator for whether an immigrant remitted any amount of money home, ${ }^{17}$ and the logarithm of the

\footnotetext{
15 Tabulations are available upon request.

${ }^{16}$ In practice, when comparing the distribution of “quitters” and "continuous remitters” across the categories in Table 2, panels $\mathrm{C}$ through $\mathrm{H}$, we find higher than average shares of both groups in both category C (spouse abroad in 1987, in U.S. in 1991) and category H (children older than 4 in the United States in 1991, but not in 1987).

${ }^{17}$ Since the dependent variable is, in this case, a zero-one dummy variable, we calculate the fraction of predictions that fall outside the unit interval and find it to be negligible (never higher than 1 percent across different specifications).
} 
dollar amount remitted. The parameter of interest is $\gamma_{1991}$-the mean post-legalization change in the dependent variable. $^{18}$

In a specification that controls for gender, age, education and documentation status at last entry, immigrants' remitting probability is estimated to decrease by 12.3 percentage points postlegalization (column 1, Table 4, panel A). The estimated drop is not significantly altered by the inclusion of U.S.-state-of-residence and country-of-origin fixed-effects (column 2). Controlling for the number of years spent in the United States, on the contrary, reduces the estimated postlegalization drop by half -to 5.4 percentage points (column 3). This suggests that around a 7percentage-point drop in the propensity to remit between 1987 and 1991 may be attributable to immigrants' assimilation - a process that would have taken place even in the absence of legalization. $^{19}$

As discussed in the previous sections, the U.S. business cycle between 1987 and 1991 may have affected migrants’ remitting patterns. To address this concern, column 4 includes the state unemployment rate as a measure of the performance of local labor markets. We find that a 1percentage-point increase in the local unemployment rate is associated with a significant 1.5percentage-point drop in the probability to remit. ${ }^{20}$ Since unemployment rates did rise on average in the early 1990s, the deterioration of the economy explains some of the observed decrease in remittances between 1987 and 1991. However, the impact of legalization is still found to be economically and statistically significant, and equal to a drop of almost 4 percentage points, i.e. a 6 percent decrease relative to the average probability of remitting money home in 1987.

\footnotetext{
Also, standard errors are always corrected for heteroskedasticity that naturally arises in a linear probability model.

${ }^{18}$ Appendix Table A2 provides details on the construction of the explanatory variables included in the regressions.

${ }^{19}$ We caution again that with only two years of data we cannot disentangle assimilation effects from cohort-of-entry effects. In particular, a negative correlation between remittances and YearsUS may stem from both remittance decay with length of stay in the host country or with stronger motives/capacity to remit of subsequent cohorts of immigrants.

${ }^{20}$ Cluster-robust standard errors at the state-year level do not differ significantly from cluster-robust standard errors at the individual level; therefore, we only report the latter in the tables.
} 
Column 5 also includes controls for the respondent's employment status and family income. To the extent that most of the impact of the economy on migrants' remitting capacity is captured by changes in their income and labor outcomes, controlling for these variables provides a robustness check for the ability of our model to purge a before-after legalization estimate from business cycle effects. Due to endogeneity concerns, we do not wish to place too much emphasis on this specification. However, the stability of the coefficient of interest across columns 4 and 5 is consistent with business cycle effects being successfully controlled for by the inclusion of state unemployment rates.

Endogeneity concerns are even stronger in the case of changes in family composition. We can, however, condition the analysis on variables measured before legalization took place. In particular, as a way to indirectly assess the role of family reunification in explaining the estimated remittance drops, we restrict the sample to married migrants whose spouse was already residing in the United States in 1987 and find results that closely resemble those obtained using the full sample (Appendix Table A3). This finding indicates that legalization may have affected remitting patterns beyond any impact via family reunification. For example, drops in remittances sent for insurance purposes may play a role in explaining some of the estimated changes.

We turn next to the question of whether remittance drops differ by country of origin. Specifications in the lower panel of Table 4 include two mutually exclusive interaction terms between the 1991 year dummy and place-of-birth dummies. Besides allowing for heterogeneous post-legalization changes, the specification in column 1, panel $\mathrm{B}$, is otherwise the same as the one in column 4, panel A, and it shows that, between 1987 and 1991, the propensity to remit significantly decreased for Mexicans (by 5.2 percentage points), but not for other Latin Americans. The fact that macroeconomic conditions in Mexico sensibly improved over the sample period raises the concern that the heterogeneous effects and, in particular, the significant drop only for Mexicans, 
may be explained by differential changes across origin groups in the needs of families and friends back home, rather than by migrants’ legalization. Against this notion, however, we find the results to be stable to the inclusion of country-of-origin time varying indicators, such as annual per capita GDP growth and average unemployment rates (panel B, columns 2 through 5). ${ }^{21}$

As shown in Table 5, very similar considerations apply when studying changes in the logarithm of the dollar amount sent home. In particular, the dollar amount remitted is estimated to decrease by approximately 25 percent post-legalization (column 5, Panel A). When exploring whether this drop differs by country of origin (Panel B), we find that remittances significantly decreased for Mexicans (by about 29 percent), but not for other Latin Americans. To assess whether changes in the amounts remitted are confounded by compositional shifts (as shown in Table 3, there is a group of “new remitters” sending home relatively low amounts), we also estimate our models using only the sample of “continuous remitters”. We find the results to be robust to this restriction (Appendix Table A4).

\section{Potential Explanations for Post-Legalization Remittance Drops among Mexicans}

The estimation results presented in the previous section suggest that IRCA negatively affected the propensity to remit of Mexican migrants, while there is no evidence of such effects among other Latin Americans. Given the potentially different remitting motives of migrants from different countries, it may well be that the acquisition of legal status had heterogeneous effects on the remitting patterns of migrants depending on their origin. However, there remain concerns that our results may be driven by some confounding factors. In particular, if remittances are sent to care for family members and friends enduring bad economic conditions back home, the recovery of the

\footnotetext{
${ }^{21}$ Column 2 (Table 4, panel B) includes the current year per capita GDP growth, column 3 includes the one-year lagged per capita GDP growth (that is, in 1986 and 1990, respectively), column 4 accounts for the average unemployment rate in the three years centered around 1987 and 1991, and column 5 includes both GDP per capita growth and the threeyear average unemployment rate.
} 
Mexican economy over the sample period may explain our finding that remittances dropped only among Mexicans. Since the LPS2 collects information on the state of birth of Mexican respondents, we exploit variation in economic conditions across Mexican states to further assess the role of the business cycle in explaining the estimated remittance drop.

Figure 2 shows the correlation between drops in the propensity to remit for respondents born in different Mexican states and changes in state macroeconomic performance, as measured by annual GDP per capita growth between 1985 and $1993 .{ }^{22}$ If drops in the propensity to remit were driven by changing needs of families back home, we may expect to find evidence of a negative correlation, with remittances decreasing more in states that grew more. If drops were driven by changing investment decisions, we may expect instead a positive correlation, with remittances decreasing more in states that did worse. As shown in Figure 2, there is no significant relationship between the two variables, which seems inconsistent with changing economic conditions in the origin communities being the driving force for the observed drops.

A second concern we may have in interpreting our findings relates to the fact that migrants can repatriate earnings either by sending remittances or by returning home with savings. If individuals were unlikely to be returning home while in the process of adjusting status, then we would expect all repatriated earnings to be in the form of remittances at the time of the first wave. After adjusting their status, however, migrants may have been more likely to visit their home country and carry money with them. If so, at the time of LPS2, some of the repatriated earnings would not be reported in the form of "money sent home". To the extent that trips home were indeed more frequent after legalization and, in particular, among Mexicans owing to geographical proximity, then differential changes across origin groups in the way money is repatriated would

\footnotetext{
${ }^{22}$ Data on GDP per capita by Mexican state (from the Instituto Nacional de Estadística y Geografia, INEGI) are available for 1985, 1988 and then yearly from 1993 on.
} 
explain why we only find remittance drops among Mexicans. Even if the LPS does not survey trips back home, we explore this possibility using information on the method used to "send" money. In both waves, migrants who sent money home were asked how they did so. The questionnaire allowed for the following options: cash, personal check, money order, bank transfer or traveler's check. Those indicating to have used another mode were asked to specify it from a further list. In both waves, the list included "other people/friends/family" and, in the LPS2, it also included "take when I visit/personally”. Even if these options clearly indicate that the question regarding the amount of money sent home was intended to capture both remittances and money brought back home during visits, we are not sure whether respondents did report both amounts. However, against the notion that earnings repatriated in person during visits may drive our findings, Table 6 documents that this is a negligible case among both Mexicans and other Latin Americans.

\section{Conclusions}

In this paper, we examine how legalization may affect immigrants’ remitting behavior. To investigate this issue, we study post-legalization changes in the propensity to remit and the amounts remitted among Latin American migrants who legalized through IRCA general amnesty program. With regard to its internal validity, a key concern in the empirical analysis is accounting for the effects of other time-varying factors contemporaneous with IRCA that might have affected migrants' remitting behavior. In models that control for immigrants' length of residence in the United States and for economic conditions in both the U.S. state of residence and the country of origin, we estimate significant post-legalization drops in both the likelihood that Mexican-born immigrants remitted money home and in the dollar amount remitted. In contrast, post-legalization changes in the remitting patterns of other Latin American immigrants are not statistically different from zero once we account for the time spent in the United States. Against the notion that post- 
legalization drops in remittances among Mexicans are explained by business cycle effects, we find these drops not to be systematically related to the macroeconomic performance of the Mexican state of origin. On the contrary, we find some evidence that the heterogeneous effects estimated for Mexicans and other Latin Americans may be explained by differences in the remitting motives across the two groups. As reported in the LPS, relative to Mexicans, legalized immigrants originating from other Latin American countries had been in the United States for shorter periods, ${ }^{23}$ were less likely to have families in the United States (both before and after legalization), and were more likely to plan to return home. ${ }^{24}$ Given their lower probability of having families in the United States, Latin Americans may have experienced smaller drops in remittances if the latter were sent altruistically. Given their higher probability to return home, they may as well have been more inclined to (continue to) remit even after legalization in order to, say, purchase a home where they could retire.

As regards the external validity of our analysis, since IRCA general amnesty program applied to immigrants who had been continuously residing in the United States since 1981, our findings can only be informative of the effects of legalization on the propensity to remit of longterm migrants. Available estimates indicate that more than a third of the undocumented population residing in the United States during the mid 2000's had lived in the country for at least 10 years (Passel, 2005; Hoefer et al., 2005). Beyond its scope, however, the most serious concerns regarding the generalization of the estimates presented in this paper arise from changes over the last two decades in the characteristics of the undocumented population, as well as from changes in the economic and political environment. Yet, in the absence of any other arguably exogenous source of identification for the effects of legalization on remittances, our analysis -with the previous

\footnotetext{
${ }^{23} 58 \%$ of them barely meet the eligibility requirement for legalization, having entered as late as 1980 or 1981 . On the contrary, a larger fraction of Mexicans entered earlier (41\% between 1974 and 1979, and 26\% before 1974).

${ }^{24}$ Fifty percent of Latin Americans plan to retire in the United States versus 63 percent of Mexicans.
} 
qualifications in mind-provides the only empirical evidence that can be used to speculate about the impact that a hypothetical current universal legalization program would have on remittance flows. ${ }^{25}$

In principle, it is not clear whether we should worry that a fall in remittances - such as the one that may follow an amnesty -would have negative consequences on the economies where immigrants originate. As long as migrants' legalization facilitates the reunification of families who were primarily spending remittances on consumption goods, concerns about the development of the economies where immigrants originate may only arise from the effects of changes in local demand on the business and employment opportunities in non-tradable sectors, or, in the case of spending in education and health, from the foregone positive externalities of human capital and health improvements. Yet, the empirical and theoretical literatures suggest that drops in remittances may have potentially detrimental effects on the economic and financial development of the originating communities. In fact, remittance flows into poor local economies may increase the scope of informal insurance or contribute to the development of a formal financial sector and, therefore, relax capital constraints for existing or new businesses. Consequently, immigrant sending countries and international development agencies may want to carefully consider the potential need for policies fostering financial development in local communities from which newly legalized emigrants originate and where reductions in remittance inflows may be larger.

\footnotetext{
${ }^{25}$ If an amnesty were to encourage more undocumented immigration, remittances could increase even if the newly legalized remit less. Assessing the general equilibrium effects of an amnesty is beyond the scope of this paper, but, as regards the case of IRCA, analyses of the flows of undocumented immigrants suggests that the amnesty program did not change long-term patterns of undocumented immigration (Orrenius and Zavodny, 2003).
} 


\section{References}

Aggarwal, Reena, Asli Demirgüç-Kunt, and Maria Soledad Martinez-Peria. 2006. “Do Workers' Remittances Promote Financial Development?” World Bank Policy Research Working Paper 3957.

Ahlburg, Dennis A., and Richard P.C. Brown. 1998. "Migrants’ Intentions to Return Home and Capital Transfers: A Study of Tongans and Samoans in Australia." The Journal of Development Studies, 35(2): 125-151.

Amuedo-Dorantes, Catalina and Susan Pozo. 2006. "Remittances and Insurance: Evidence from Mexican Migrants.” Journal of Population Economics, 19(2): 227-254.

Amuedo-Dorantes, Catalina, Pozo, Susan, and Tania Sainz. 2007. "Remittances and Healthcare Expenditure Patterns of Populations in Origin Communities: Evidence from Mexico.” Integration \& Trade Journal, 27: 159-184.

Angelucci, Manuela and Giacomo De Giorgi. 2009. “Indirect Effects of an Aid Program: How Do Cash Transfers Affect Ineligibles’ Consumption?” American Economic Review, 99 (1): 486508.

Becker, Gary. 1974. “A theory of social interactions.” Journal of Political Economy, 82: 1063-93.

Borjas, George. 1985. "Assimilation, changes in cohort quality and the earnings of immigrants", Journal of Labor Economics, 3 (4): 463-489.

Cañas, Jesus, Roberto Coronado and Pia Orrenius. 2007. "Explaining the Increase in Remittances to Mexico”, Southwest Economy, Issue 4, Federal Reserve Bank of Dallas

Cooper, Betsy, and Kevin O’Neil. 2005. “Lessons from the Immigration Reform and Control Act of 1986”. Migration Policy Institute Policy Brief, No. 3, Migration Policy Institute, Washington D.C.

Cox-Edwards, Alejandra and Manuelita Ureta. 2003. "International Migration, Remittances, and Schooling: Evidence from El Salvador”, Journal of Development Economics, 72: 429-461.

Durand Jorge, Kandel William, Parrado Emilio A., Massey Douglas S. 1996. "International Migration and Development in Mexican Communities.” Demography 33(2): 249-64.

Edwards, Sebastian. 2004. "Thirty Years of Current Account Imbalances, Current Account Reversals, and Sudden Stops”, IMF Staff Papers, vol. 51 (special issue).

Fafchamps, Marcel and Lund, Susan. 2003. "Risk-sharing Networks in Rural Philippines.” Journal of Development Economics, 71(2): 261-87.

Glytsos, Nicholas P. 1997. "Remitting Behaviour of 'Temporary' and 'Permanent' Migrants: the Case of Greeks in Germany and Australia.” Labour, 11(3): 409-35.

Hagan, Jacqueline M. 1994. Deciding to Be Legal: A Maya Community in Houston. Temple University Press, Philadelphia.

Hanson, Gordon and Christopher Woodruff. 2003. "Emigration and Educational Attainment in Mexico”, Mimeo, University of California, San Diego.

Hoefer, Michael. 1991. "Background of U.S. Immigration Policy Reform”, in U.S. Immigration Policy Reform in the 1980s: A Preliminary Assessment, edited by Francisco L. RiveraBatiz, S. L. Sechzer, and I. N. Gang. New York: Praeger; pp. 17-44.

Hoefer, Michael, Nancy Rytina and Christopher Campbell. 2005. Estimates of the Unauthorized Immigrant Population Residing in the United States: January 2005. Population Estimates (August 2006), U.S. Department of Homeland Security, Office of Immigration Statistics.

Immigration and Naturalization Service. 1998. 1996 Statistical Yearbook of the Immigration and Naturalization Service, U.S. Department of Justice. 
Immigration and Naturalization Service. 2002. 2000 Statistical Yearbook of the Immigration and Naturalization Service, U.S. Department of Justice.

Inter-American Development Bank. 2007. "Sending Money Home. Worldwide Remittance Flows to Developing Countries” available at: http://idbdocs.iadb.org/wsdocs/getdocument.aspx?docnum=1172190.

Kanaiaupuni, Shawn and Katherine Donato. 1999. "Migradollars and Mortality: The Effects of Migration on Infant Survival in Mexico”, Demography, 36: 339-353.

Kaushal, Neeraj. 2006. "Amnesty Programs and the Labor Market Outcomes of Undocumented Workers.” Journal of Human Resources, 61(3): 631-647.

Kossoudji, Sherrie A and Deborah Cobb-Clark. 2002. "Coming Out of the Shadows: Learning about Legal Status and Wages from the Legalized Population." Journal of Labor Economics, 20(3): 598-628.

Lucas, Robert E. B. and Oded Stark. 1985. "Motivations to Remit: Evidence from Bostwana." Journal of Political Economy, 93(5): 901-18.

Massey, Douglas and Emilio Parrado. 1998. "International Migration and Business Formation in Mexico”, Social Science Quarterly, 79(1): 1-20.

Menjivar, Cecilia, Julie S. DaVanzo, Lisa Greenwell, and R. B. Valdez. 1998. "Remittance Behavior Among Salvadoran and Filipino Immigrants in Los Angeles," International Migration Review, 32(1): 97-126.

Milesi-Ferretti, G. M. and A. Razin. 1998. "Sharp Reductions in Current Account Deficits: An Empirical Analysis”, European Economic Review, 42: 897-908.

Milesi-Ferreti, G. M. and A. Razin. 2000. "Current Account Reversals and Currency Crises: Empirical Regularities” in P. Krugman (editor), Currency Crises, Chicago: University of Chicago Press.

Office of Policy and Planning. 2003. "Estimates of the Unauthorized Immigrant Population Residing in the United States: 1990 to 2000” U.S. Immigration and Naturalization Service, U.S. Department of Justice.

Orozco, Manuel, B. Lindsay Lowell, Micah Bump, and Rachel Fedewa. 2005. "Transnational Engagement, Remittances and their Relationship to Development in Latin America and the Caribbean”, Institute for the Study of International Migration, Georgetown University

Orrenius, Pia and Madeline Zavodny. 2003. "Do Amnesty Programs Reduce Undocumented Immigration? Evidence from IRCA.” Demography, 40(3): 437-450.

Passel, Jeffrey. 2005. Unauthorized Migrants: Numbers and Characteristics. Background Briefing Prepared for Task Force on Immigration and America's Future. Pew Hispanic Center: Washington, D.C.

Passel, Jeffrey. 2006. Estimates of the Size and Characteristics of the Undocumented Population. March Report from the Pew Hispanic Center: Washington, D.C.

Rosenzweig, Mark. 1988a. "Risk, Private Information, and the Family.” American Economic Review, 78(2): 245-50.

Rosenzweig, Mark. 1988b. "Risk, Implicit Contracts and the Family in Rural Areas of Low-Income Countries.” The Economic Journal, 98(393): 1148-70.

Ratha, Dilip. 2006. “Trends, Determinants and Macroeconomic Effects of Remittances,” in Global Economic Prospects 2006: Economic Implications of Remittances and Migration, Washington DC, The International Bank for Reconstruction and Development, the World Bank, 2006, pp. 85-115. 
Rytina, Nancy. 2002. “IRCA Legalization Effects: Lawful Permanent Residence and Naturalization through 2001.” Working Paper. Office of Policy and Planning, Statistics Division, U.S. Immigration and Naturalization Service.

Sudman, Seymour and Norman M. Bradburn. 1973. "Effects of Time and Memory Factors on Response in Surveys,” Journal of the American Statistical Association, 68(344): 805-815

Stark, Oded. 1991. The Migration of Labour. Oxford: Basil Blackwell.

Taylor, Edward J. 1999. "The New Economics of Labour Migration and the Role of Remittances in the Migration Process.” International Migration, 37(1): 63-88.

Townsend, Robert. 1995. "Financial Systems in Northern Thai Villages." Quarterly Journal of Economics, 110(4): 1011-46.

Udry, Christopher. 1994. "Risk and Insurance in a Rural Credit Market: An Empirical Investigation in Northern Nigeria.” Review of Economic Studies, 61(3): 495-526.

Warren, Robert. 1995. "Estimates of the Undocumented Immigrant Population Residing in the United States by Country of Origin and State of Residence: October 1992.” Unpublished. U.S. Immigration and Naturalization Service.

Woodruff, Christopher and René Zenteno. 2007. "Migration Networks and Microentreprises in Mexico”, Journal of Development Economics, 82(2): 509-528.

Yang, Dean. 2008. “International Migration, Remittances, and Household Investment: Evidence from Philippine Migrants’ Exchange Rate Shocks”, The Economic Journal, 118(528): 591630. 
Table 1

Descriptive Statistics

\begin{tabular}{|c|c|c|c|c|c|c|}
\hline \multirow{2}{*}{ Immigrants From: } & \multicolumn{2}{|c|}{ All Countries } & \multicolumn{2}{|c|}{ Mexico } & \multicolumn{2}{|c|}{ Other Latin America } \\
\hline & 1987 & 1991 & 1987 & 1991 & 1987 & 1991 \\
\hline Fraction remitting & 66.3 & 55.0 & 64.7 & 52.4 & 71.1 & 63.3 \\
\hline \$ Amount remitted (if $>0$ ) & $\$ 2,100$ & $\$ 1,614$ & $\$ 2,199$ & $\$ 1,629$ & $\$ 1,815$ & $\$ 1,573$ \\
\hline \multicolumn{7}{|l|}{ Economic indicators: } \\
\hline \multicolumn{7}{|l|}{ U.S. State $\mathrm{e}^{(\mathrm{a})}$} \\
\hline Unemployment rate (\%) & 6.4 & 7.4 & 6.5 & 7.4 & 5.9 & 7.3 \\
\hline \multicolumn{7}{|l|}{ Country of origin ${ }^{(b)}$} \\
\hline Per capita GDP \% growth & 0.31 & 2.15 & -0.15 & 2.30 & 1.78 & 1.66 \\
\hline Per capita GDP \% growth (lagged) & -4.33 & 2.64 & -5.69 & 3.10 & -0.06 & 1.17 \\
\hline Unemp. rate (\%) (3-year avg) & 3.9 & 4.4 & 2.5 & 3.1 & 8.9 & 8.6 \\
\hline Male & 0.55 & 0.55 & 0.57 & 0.57 & 0.51 & 0.51 \\
\hline Age & 31.9 & 35.9 & 31.3 & 35.3 & 33.8 & 37.8 \\
\hline Years in the United States. & 9.9 & 13.9 & 10.4 & 14.4 & 8.4 & 12.4 \\
\hline Undocumented at last entry & 0.83 & 0.83 & 0.85 & 0.85 & 0.74 & 0.74 \\
\hline Less than 12 years of education & 0.78 & 0.77 & 0.84 & 0.83 & 0.60 & 0.60 \\
\hline \multicolumn{7}{|l|}{ State of residence } \\
\hline CA & 0.61 & 0.61 & 0.65 & 0.65 & 0.48 & 0.48 \\
\hline $\mathrm{TX}$ & 0.14 & 0.14 & 0.15 & 0.15 & 0.09 & 0.09 \\
\hline NJ, NY, IL, FL & 0.17 & 0.17 & 0.11 & 0.11 & 0.35 & 0.35 \\
\hline Employed & 0.80 & 0.77 & 0.78 & 0.75 & 0.86 & 0.80 \\
\hline \multicolumn{7}{|l|}{ Family Income } \\
\hline less than $\$ 15,000$ & 0.36 & 0.29 & 0.35 & 0.29 & 0.39 & 0.29 \\
\hline$\$ 15,000-\$ 29,999$ & 0.37 & 0.38 & 0.38 & 0.39 & 0.35 & 0.36 \\
\hline$\$ 30,000$ or more & 0.16 & 0.24 & 0.16 & 0.23 & 0.16 & 0.26 \\
\hline Spouse abroad & 0.04 & 0.04 & 0.05 & 0.03 & 0.03 & 0.04 \\
\hline Spouse in U.S. & 0.61 & 0.71 & 0.62 & 0.73 & 0.56 & 0.64 \\
\hline Observations & 3,158 & 3,158 & 1,787 & 1,787 & 1,371 & 1,371 \\
\hline
\end{tabular}

Notes: Sample restricted to individuals at least 16 years old, born in a Latin American country, and interviewed in both waves. Since non-Mexicans are sampled at about 2.6 times the rate of the Mexican-born, all figures are weighted.

Source: Legalized Population Survey, (a) U.S. Bureau of Labor Statistics, (b) The World Bank. 
Table 2

Percentage Remitting Money Home by Time of Application and Likelihood of Family Reunification

\begin{tabular}{|c|c|c|c|c|}
\hline Category of Respondents & $\begin{array}{c}\text { Share of the } \\
\text { Balanced LPS } \\
\text { Sample }\end{array}$ & 1987 & 1991 & $\begin{array}{l}\text { 1987-91 } \\
\text { \% Change }\end{array}$ \\
\hline All & 100 & 66.3 & 55.0 & -11.3 \\
\hline \multicolumn{5}{|l|}{ When applied for temporary resident status } \\
\hline A. Applicant 1987 & 56.6 & 65.1 & 53.2 & -11.9 \\
\hline B. Applicant 1988 & 43.4 & 67.7 & 57.4 & -10.3 \\
\hline \multicolumn{5}{|l|}{ Whether likely to have reunified with spouse or partner } \\
\hline C. Spouse abroad in 1987, in U.S. in 1991 & 1.9 & 91.4 & 59.9 & $-31.5^{* * *}$ \\
\hline D. Not married in 1987, spouse in U.S. in 1991 & 13.0 & 68.9 & 55.8 & -13.1 \\
\hline E. Not married either in 1987 or in 1991 & 20.3 & 62.6 & 50.2 & -12.4 \\
\hline F. Spouse in U.S. both in 1987 and 1991 & 55.2 & 65.3 & 55.1 & -10.2 \\
\hline G. Spouse abroad both in 1987 and 1991 & 1.8 & 95.6 & 87.9 & -7.7 \\
\hline \multicolumn{5}{|c|}{ Whether likely to have brought children to the United States } \\
\hline H. Children older than 4 in U.S. in 1991, not in 1987 & 8.9 & 76.2 & 57.6 & $-18.6^{* *}$ \\
\hline I. No children older than 4 in U.S. in 1991 & 28.4 & 71.4 & 60.1 & -11.3 \\
\hline
\end{tabular}

Notes: *** indicates that the mean for the group is statistically different from the mean for the rest of the sample at 1 percent significance level, ** 5 percent significance level, * 10 percent significance level.

Source: Legalized Population Survey. 
Table 3

Changes in Remitting Practices Before and After Legalization

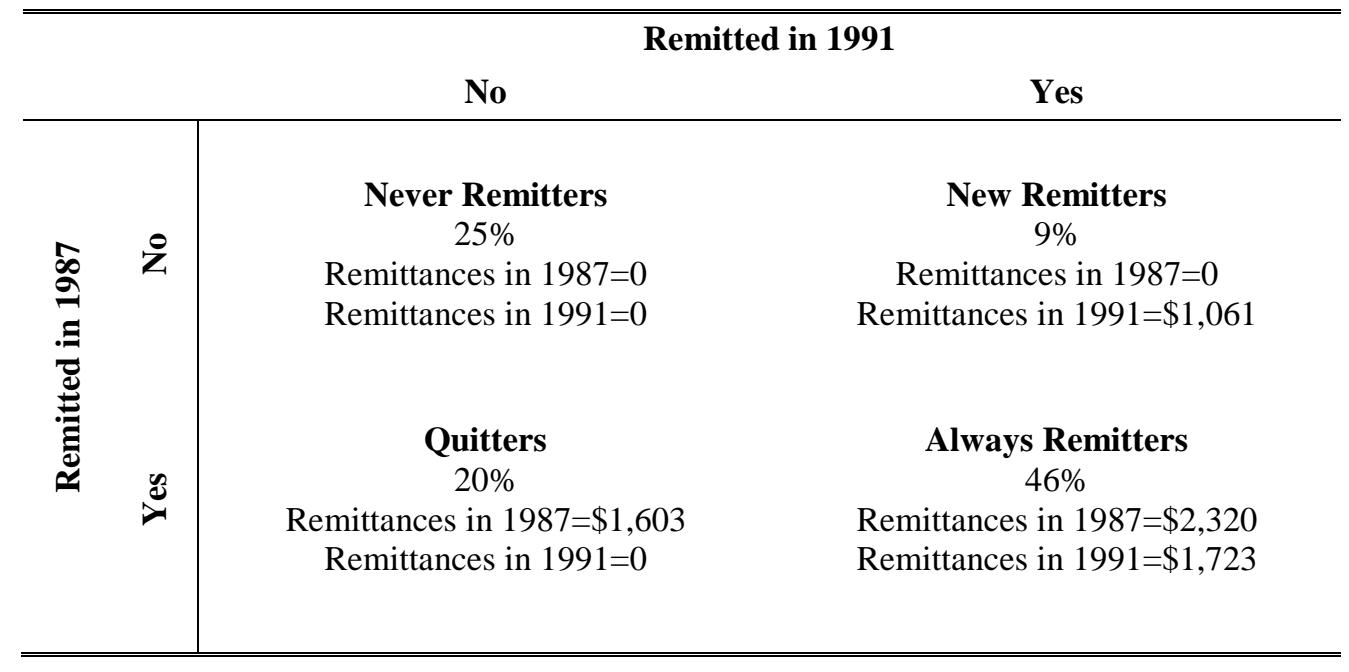

Notes: The table reports the percentage of respondents who changed or not their remitting behavior between 1987 and 1991 (the figures sum to 100). It also reports the average amount remitted by each group in each year (figures are in 1991 dollars).

Sample: LPS balanced panel of 3,158 individuals at least 16 years old. 
Table 4

Before-After Estimates of the Effects of Legalization on the Propensity to Remit

Model Specifications

(1)

(2)

(3)

(4)

(5)

A. Homogenous effects

\begin{tabular}{|c|c|c|c|c|c|}
\hline Year 1991 & $\begin{array}{c}-0.123 * * * \\
(0.011)\end{array}$ & $\begin{array}{c}-0.117 * * * \\
(0.011)\end{array}$ & $\begin{array}{c}-0.054 * * * \\
(0.014)\end{array}$ & $\begin{array}{c}-0.039 * * \\
(0.015)\end{array}$ & $\begin{array}{c}-0.039 * * \\
(0.016)\end{array}$ \\
\hline Male & $\begin{array}{c}0.135^{* * *} \\
(0.015)\end{array}$ & $\begin{array}{c}0.140 * * * \\
(0.015)\end{array}$ & $\begin{array}{c}0.144^{* * *} \\
(0.015)\end{array}$ & $\begin{array}{c}0.144^{* * *} \\
(0.015)\end{array}$ & $\begin{array}{c}0.066^{* * *} \\
(0.017)\end{array}$ \\
\hline Age & $\begin{array}{c}0.021^{* * *} \\
(0.004)\end{array}$ & $\begin{array}{c}0.017 * * * \\
(0.004)\end{array}$ & $\begin{array}{c}0.025^{* * *} \\
(0.004)\end{array}$ & $\begin{array}{c}0.025^{* * *} \\
(0.004)\end{array}$ & $\begin{array}{c}0.019 * * * \\
(0.004)\end{array}$ \\
\hline Age squared & $\begin{array}{c}-0.027 * * * \\
(0.004)\end{array}$ & $\begin{array}{c}-0.024^{* * *} \\
(0.004)\end{array}$ & $\begin{array}{c}-0.031^{* * *} \\
(0.005)\end{array}$ & $\begin{array}{c}-0.031 * * * \\
(0.005)\end{array}$ & $\begin{array}{c}-0.023 * * * \\
(0.005)\end{array}$ \\
\hline Undocumented at entry & $\begin{array}{c}0.129 * * * \\
(0.022)\end{array}$ & $\begin{array}{c}0.115^{* * *} \\
(0.023)\end{array}$ & $\begin{array}{c}0.090 * * * \\
(0.023)\end{array}$ & $\begin{array}{c}0.090^{* * *} \\
(0.023)\end{array}$ & $\begin{array}{c}0.077 * * * \\
(0.024)\end{array}$ \\
\hline At most $5^{\text {th }}$ grade & $\begin{array}{c}0.043 \\
(0.028)\end{array}$ & $\begin{array}{c}0.081^{* * *} \\
(0.030)\end{array}$ & $\begin{array}{c}0.079 * * * \\
(0.029)\end{array}$ & $\begin{array}{c}0.079 * * * \\
(0.029)\end{array}$ & $\begin{array}{c}0.140^{* * *} \\
(0.030)\end{array}$ \\
\hline $6^{\text {th }}-11^{\text {th }}$ grade & $\begin{array}{c}0.044^{*} \\
(0.026)\end{array}$ & $\begin{array}{l}0.066 * * \\
(0.026)\end{array}$ & $\begin{array}{c}0.060 * * \\
(0.026)\end{array}$ & $\begin{array}{l}0.059 * * \\
(0.026)\end{array}$ & $\begin{array}{c}0.104 * * * \\
(0.027)\end{array}$ \\
\hline $12^{\text {th }}$ grade/ HS diploma & $\begin{array}{c}0.027 \\
(0.028)\end{array}$ & $\begin{array}{r}0.025 \\
(0.028)\end{array}$ & $\begin{array}{c}0.022 \\
(0.028)\end{array}$ & $\begin{array}{r}0.020 \\
(0.028)\end{array}$ & $\begin{array}{r}0.051^{*} \\
(0.029)\end{array}$ \\
\hline Years in U.S. & & & $\begin{array}{c}-0.032 * * * \\
(0.005)\end{array}$ & $\begin{array}{c}-0.036^{* * *} \\
(0.006)\end{array}$ & $\begin{array}{r}-0.036 * * * \\
(0.006)\end{array}$ \\
\hline Years in U.S. squared & & & $\begin{array}{c}0.001 * * * \\
(0.000)\end{array}$ & $\begin{array}{c}0.001 * * * \\
(0.000)\end{array}$ & $\begin{array}{c}0.001 * * * \\
(0.000)\end{array}$ \\
\hline U.S.-State Unemployment Rate (\%) & & & & $\begin{array}{c}-0.015^{* *} \\
(0.008)\end{array}$ & $\begin{array}{l}-0.010 \\
(0.007)\end{array}$ \\
\hline U.S. State FE & NO & YES & YES & YES & YES \\
\hline Origin-country FE & NO & YES & YES & YES & YES \\
\hline Individual economic variables & NO & NO & NO & NO & YES \\
\hline \multicolumn{6}{|l|}{ B. Heterogeneous effects } \\
\hline Year $1991 *$ Mexico & $\begin{array}{c}-0.052 * * * \\
(0.017)\end{array}$ & $\begin{array}{c}-0.075^{* * *} \\
(0.020)\end{array}$ & $\begin{array}{c}-0.065^{* *} \\
(0.032)\end{array}$ & $\begin{array}{c}-0.049 * * * \\
(0.017)\end{array}$ & $\begin{array}{c}-0.079 * * * \\
(0.021)\end{array}$ \\
\hline Year 1991 * other Latin America & $\begin{array}{c}0.018 \\
(0.020)\end{array}$ & $\begin{array}{r}0.018 \\
(0.020)\end{array}$ & $\begin{array}{r}0.015 \\
(0.021)\end{array}$ & $\begin{array}{c}0.012 \\
(0.020)\end{array}$ & $\begin{array}{r}0.009 \\
(0.021)\end{array}$ \\
\hline U.S. State Unemployment Rate (\%) & $\begin{array}{c}-0.018^{* * *} \\
(0.006)\end{array}$ & $\begin{array}{c}-0.018^{* * *} \\
(0.006)\end{array}$ & $\begin{array}{c}-0.018^{* * *} \\
(0.006)\end{array}$ & $\begin{array}{c}-0.019 * * * \\
(0.006)\end{array}$ & $\begin{array}{r}-0.019 * * * \\
(0.006)\end{array}$ \\
\hline $\begin{array}{l}\text { Origin country annual GDP } \\
\text { per capita growth }\end{array}$ & & $\begin{array}{l}0.009 * * \\
(0.004)\end{array}$ & & & $\begin{array}{l}0.012 * * \\
(0.005)\end{array}$ \\
\hline $\begin{array}{l}\text { Origin country annual GDP } \\
\text { per capita growth (lagged) }\end{array}$ & & & $\begin{array}{r}0.001 \\
(0.003)\end{array}$ & & \\
\hline $\begin{array}{l}\text { Origin country three-years } \\
\text { Average Unemployment rate (\%) }\end{array}$ & & & & $\begin{array}{c}-0.004 \\
(0.004)\end{array}$ & $\begin{array}{l}-0.004 \\
(0.004)\end{array}$ \\
\hline U.S. State FE & NO & YES & YES & YES & YES \\
\hline Origin-country FE & NO & YES & YES & YES & YES \\
\hline
\end{tabular}

Notes: Pooled OLS weighted estimates. All regressions include a constant term. Models in panel B include the individual controls included in column 4 of panel A. Standard errors (in parentheses) account for correlation across observations for the same individual. * significant at 10 percent, ** significant at 5 percent, *** significant at 1 percent. Sample: LPS balanced panel of 6,316 individuals at least 16 years old. 
Table 5

Before-After Estimates of the Effects of Legalization on the (Log) of the Amounts Remitted

Model Specifications

(1)

(2)

(3)

(4)

(5)

\section{A. Homogenous Effects}

\begin{tabular}{|c|c|c|c|c|c|}
\hline Year 1991 & $\begin{array}{c}-0.306^{* * *} \\
(0.036)\end{array}$ & $\begin{array}{c}-0.311^{* * *} \\
(0.036)\end{array}$ & $\begin{array}{r}-0.225 * * * \\
(0.046)\end{array}$ & $\begin{array}{c}-0.229 * * * \\
(0.052)\end{array}$ & $\begin{array}{r}-0.253 * * * \\
(0.054)\end{array}$ \\
\hline Male & $\begin{array}{c}0.485^{* * *} \\
(0.044)\end{array}$ & $\begin{array}{r}0.485^{* * *} \\
(0.045)\end{array}$ & $\begin{array}{r}0.492 * * * \\
(0.045)\end{array}$ & $\begin{array}{c}0.492^{* * *} \\
(0.045)\end{array}$ & $\begin{array}{r}0.368 * * * \\
(0.048)\end{array}$ \\
\hline Age & $\begin{array}{l}-0.000 \\
(0.012)\end{array}$ & $\begin{array}{c}-0.001 \\
(0.012)\end{array}$ & $\begin{array}{r}0.013 \\
(0.013)\end{array}$ & $\begin{array}{r}0.013 \\
(0.013)\end{array}$ & $\begin{array}{c}-0.005 \\
(0.014)\end{array}$ \\
\hline Age squared & $\begin{array}{c}-0.001 \\
(0.014)\end{array}$ & $\begin{array}{r}0.000 \\
(0.015)\end{array}$ & $\begin{array}{c}-0.015 \\
(0.015)\end{array}$ & $\begin{array}{c}-0.015 \\
(0.015)\end{array}$ & $\begin{array}{r}0.013 \\
(0.017)\end{array}$ \\
\hline Undocumented at entry & $\begin{array}{l}0.144^{* *} \\
(0.067)\end{array}$ & $\begin{array}{r}0.089 \\
(0.073)\end{array}$ & $\begin{array}{r}0.059 \\
(0.076)\end{array}$ & $\begin{array}{r}0.059 \\
(0.076)\end{array}$ & $\begin{array}{r}0.075 \\
(0.076)\end{array}$ \\
\hline At most $5^{\text {th }}$ grade & $\begin{array}{c}-0.235^{* * *} \\
(0.083)\end{array}$ & $\begin{array}{r}-0.291^{* * *} \\
(0.088)\end{array}$ & $\begin{array}{r}-0.287 * * * \\
(0.087)\end{array}$ & $\begin{array}{c}-0.287 * * * \\
(0.087)\end{array}$ & $\begin{array}{c}-0.145 \\
(0.089)\end{array}$ \\
\hline $6^{\text {th }}-11^{\text {th }}$ grade & $\begin{array}{c}-0.009 \\
(0.075)\end{array}$ & $\begin{array}{l}-0.065 \\
(0.078)\end{array}$ & $\begin{array}{c}-0.067 \\
(0.078)\end{array}$ & $\begin{array}{c}-0.066 \\
(0.078)\end{array}$ & $\begin{array}{r}0.017 \\
(0.079)\end{array}$ \\
\hline $12^{\text {th }}$ grade/ HS diploma & $\begin{array}{c}-0.095 \\
(0.084)\end{array}$ & $\begin{array}{l}-0.125 \\
(0.085)\end{array}$ & $\begin{array}{c}-0.133 \\
(0.085)\end{array}$ & $\begin{array}{c}-0.132 \\
(0.085)\end{array}$ & $\begin{array}{c}-0.100 \\
(0.087)\end{array}$ \\
\hline Years in U.S. & & & $\begin{array}{r}-0.051 * * * \\
(0.018)\end{array}$ & $\begin{array}{c}-0.051^{* * *} \\
(0.018)\end{array}$ & $\begin{array}{c}-0.076 * * * \\
(0.019)\end{array}$ \\
\hline Years in U.S. squared & & & $\begin{array}{l}0.001 * * \\
(0.001)\end{array}$ & $\begin{array}{l}0.001 * * \\
(0.001)\end{array}$ & $\begin{array}{c}0.002 * * * \\
(0.001)\end{array}$ \\
\hline U.S.-State Unemployment Rate (\%) & & & & $\begin{array}{r}0.004 \\
(0.020)\end{array}$ & $\begin{array}{r}0.007 \\
(0.021)\end{array}$ \\
\hline U.S. State FE & NO & YES & YES & YES & YES \\
\hline Origin-country FE & NO & YES & YES & YES & YES \\
\hline Individual economic variables & NO & NO & NO & NO & YES \\
\hline \multicolumn{6}{|l|}{ B. Heterogeneous Effects } \\
\hline Year $1991 *$ Mexico & $\begin{array}{c}-0.281^{* * *} \\
(0.057)\end{array}$ & $\begin{array}{r}-0.255^{* * *} \\
(0.069)\end{array}$ & $\begin{array}{c}-0.022 \\
(0.113)\end{array}$ & $\begin{array}{c}-0.263 * * * \\
(0.058)\end{array}$ & $\begin{array}{c}-0.287 * * * \\
(0.075)\end{array}$ \\
\hline Year 1991* other Latin America & $\begin{array}{c}-0.038 \\
(0.064)\end{array}$ & $\begin{array}{l}-0.041 \\
(0.064)\end{array}$ & $\begin{array}{r}0.002 \\
(0.068)\end{array}$ & $\begin{array}{c}-0.082 \\
(0.064)\end{array}$ & $\begin{array}{l}-0.083 \\
(0.064)\end{array}$ \\
\hline U.S. State Unemployment Rate (\%) & $\begin{array}{c}-0.007 \\
(0.021)\end{array}$ & $\begin{array}{c}-0.007 \\
(0.021)\end{array}$ & $\begin{array}{c}-0.008 \\
(0.021)\end{array}$ & $\begin{array}{c}-0.009 \\
(0.021)\end{array}$ & $\begin{array}{c}-0.009 \\
(0.021)\end{array}$ \\
\hline $\begin{array}{l}\text { Origin country annual GDP } \\
\text { per capita growth }\end{array}$ & & $\begin{array}{l}-0.011 \\
(0.016)\end{array}$ & & & $\begin{array}{r}0.016 \\
(0.020)\end{array}$ \\
\hline $\begin{array}{l}\text { Origin country annual GDP } \\
\text { per capita growth (lagged) }\end{array}$ & & & $\begin{array}{r}-0.029 * * * \\
(0.011)\end{array}$ & & \\
\hline $\begin{array}{l}\text { Origin country three-years } \\
\text { Average Unemployment rate (\%) }\end{array}$ & & & & $\begin{array}{l}-0.026 * \\
(0.014)\end{array}$ & $\begin{array}{l}-0.026 * \\
(0.014)\end{array}$ \\
\hline U.S. State FE & NO & YES & YES & YES & YES \\
\hline Origin-country FE & NO & YES & YES & YES & YES \\
\hline
\end{tabular}

Notes: Pooled OLS weighted estimates. Regressions include a constant term. Standard errors (in parentheses) account for correlation across observations for the same individual. * significant at 10 percent, ** significant at 5 percent, *** significant at 1 percent. Sample: LPS balanced panel of 3,886 individuals at least 16 years old. 
Table 6

Remitting Methods Before and After Legalization

\begin{tabular}{|c|c|c|c|c|c|c|}
\hline \multirow{2}{*}{ Immigrants From } & \multicolumn{2}{|c|}{ All countries } & \multicolumn{2}{|c|}{ Mexico } & \multicolumn{2}{|c|}{ Other Latin Americans } \\
\hline & 1987 & 1991 & 1987 & 1991 & 1987 & 1991 \\
\hline Cash & 16,7 & 23,6 & 16,8 & 24,9 & 16,5 & 20,4 \\
\hline Personal check & 1,7 & 2,2 & 1,8 & 2,2 & 1,4 & 2,3 \\
\hline Money order & 73,7 & 60,4 & 76,1 & 61,9 & 66,7 & 56,4 \\
\hline Transfer from a bank & 5,0 & 6,4 & 2,9 & 4,0 & 11,1 & 12,6 \\
\hline Traveler's Check & 0,2 & 0,8 & 0,1 & 0,7 & 0,4 & 1,1 \\
\hline Some other way: & 2,6 & 6,2 & 2,3 & 5,9 & 3,7 & 6,8 \\
\hline Someone going there & 1,6 & 3,0 & 1,2 & 2,7 & 2,6 & 3,7 \\
\hline Take when visit/personally & NA & 0,2 & NA & 0,2 & NA & 0,3 \\
\hline Other & 1,1 & 3,0 & 1,0 & 3,0 & 1,2 & 2,9 \\
\hline No answer & 0,1 & 0,4 & 0,1 & 0,3 & 0,1 & 0,4 \\
\hline
\end{tabular}


Figure 1

Remittances to Mexico

\section{A. Remittances 1980-2006}

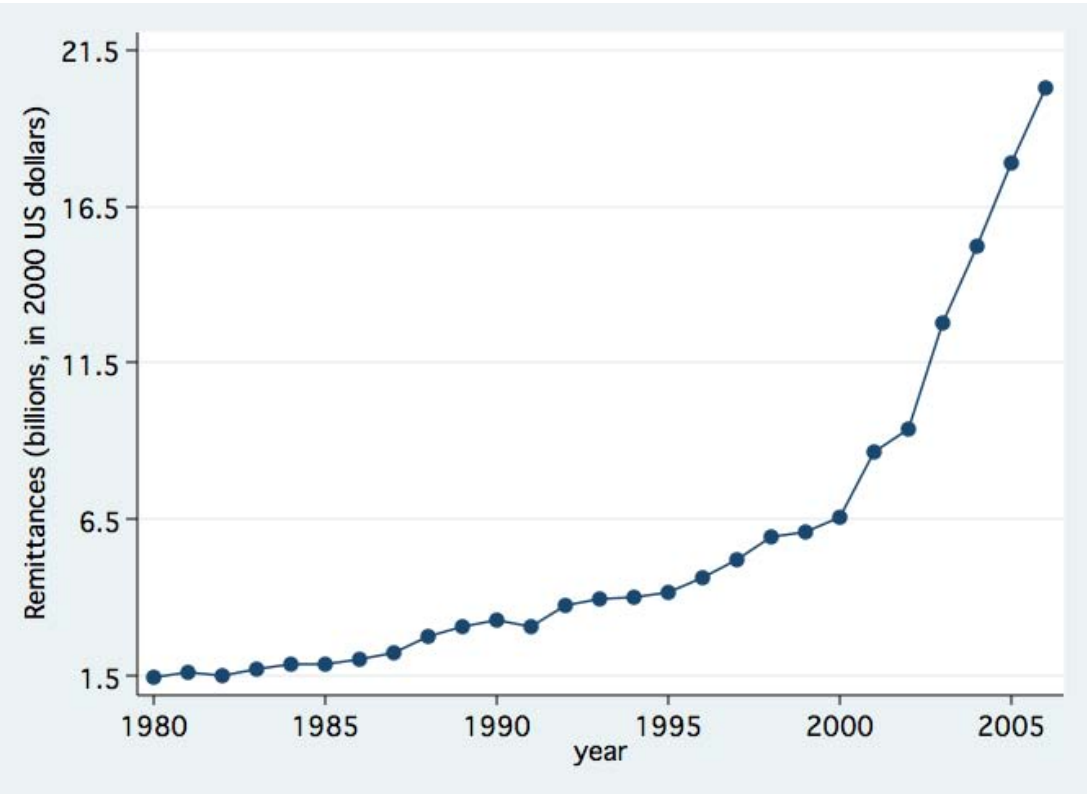

B. Remittances 1980-1995: Measured and Predicted

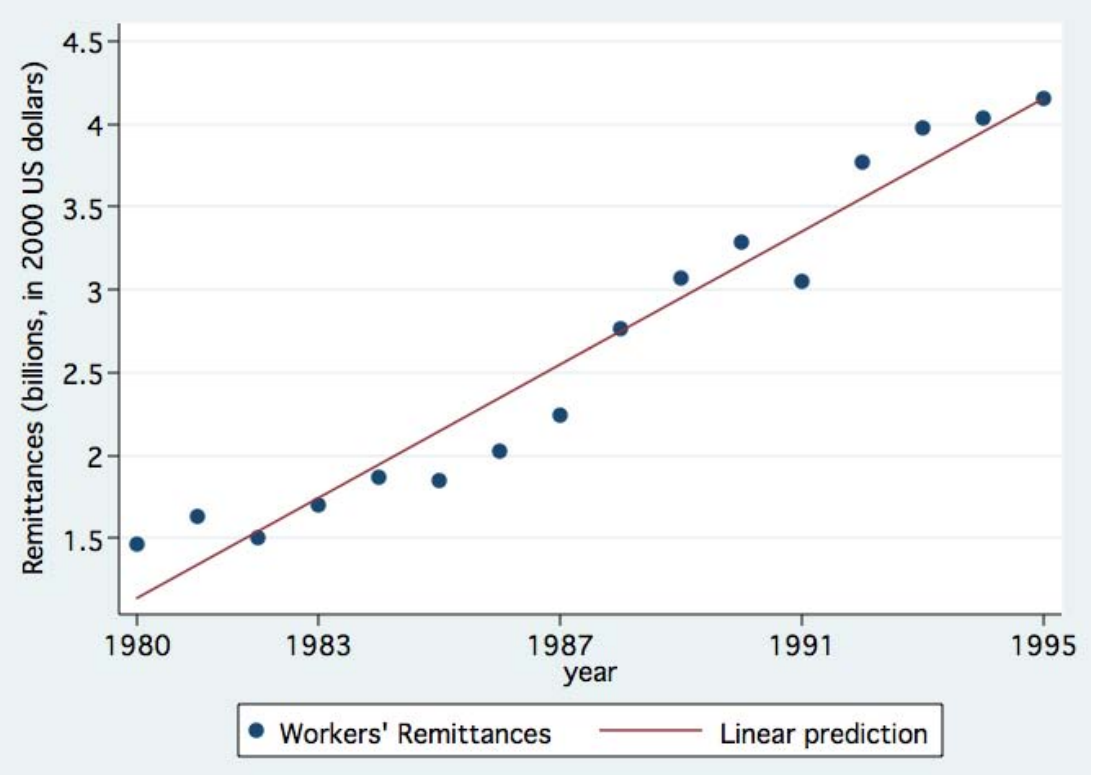

Notes: Graphs report remittances sent to Mexico by Mexican-born workers who were employed or intended to remain employed for more than a year in another country. Figures are deflated by the CPI index $(2000=1)$ and are from the World Bank (WDI). 
Figure 2

Remittances and Annual Per Capita GDP Growth Rate in Mexican States

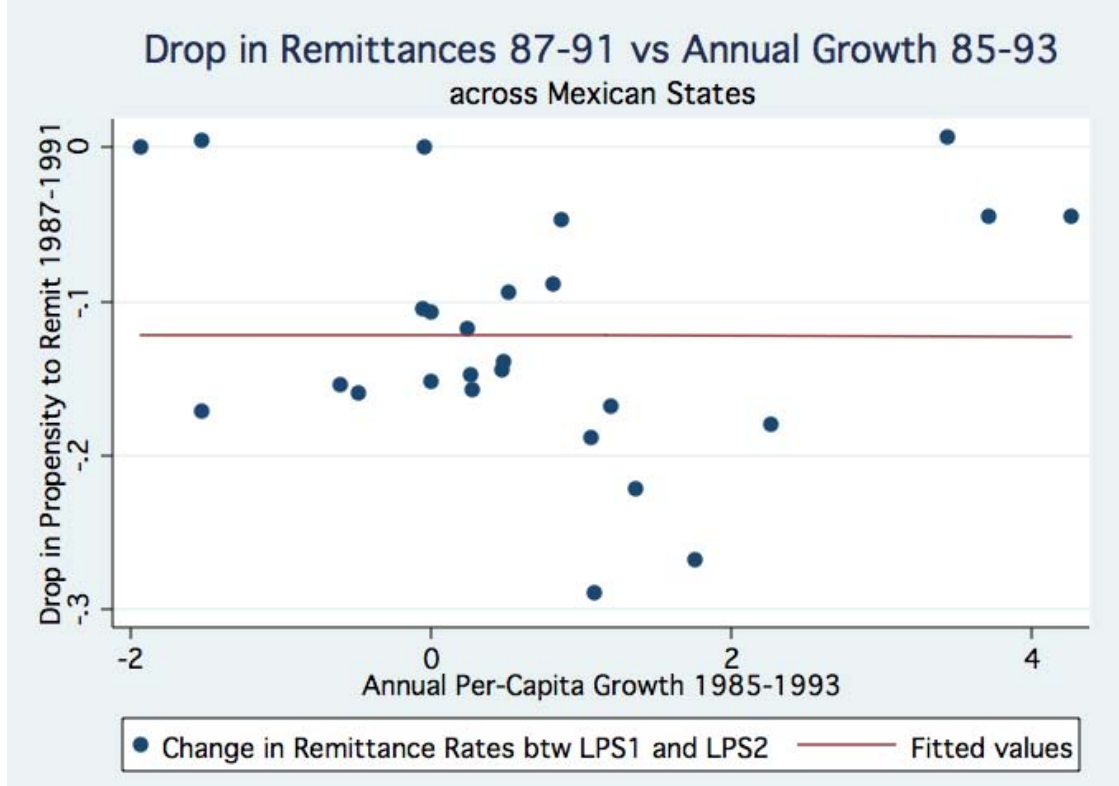

Notes: Figures on annual per capita growth by Mexican state are from the Instituto Nacional de Estadística y Geografia (INEGI). 
Table A1

Sources of Attrition in the Legalized Population Survey

\begin{tabular}{|c|c|c|}
\hline & Respondents & Comments \\
\hline LPS1 Sample & 6,193 & $\begin{array}{l}\text { Universe: Population of adult legalization } \\
\text { applicants to IRCA general amnesty program by } \\
\text { January } 1989 \text { ("pre-1982 immigrants") }\end{array}$ \\
\hline LPS2 Sample & 4,012 & $\begin{array}{l}\text { Universe: Legalization applicants who were } \\
\text { granted LPR status by January } 1992\end{array}$ \\
\hline Not sampled for LPS2 & 1,193 & \\
\hline Ineligible in January 1992 & 502 & Not in the universe \\
\hline Not in the Legalization Application & 3 & Not in the universe \\
\hline \multicolumn{3}{|l|}{ Processing System file } \\
\hline Known dead & 2 & Not in the universe \\
\hline No decision & 471 & Not in the universe \\
\hline Awaiting information & 18 & Not in the universe \\
\hline Denied & 4 & Not in the universe \\
\hline Terminated & 5 & Not in the universe \\
\hline Others excluded from sample & 691 & $\begin{array}{l}\text { Randomly selected for exclusion because of } \\
\text { resource limitations }\end{array}$ \\
\hline Sampled, but later found to be ineligible & 98 & \\
\hline Left U.S. permanently & 70 & \\
\hline Known to be dead & 28 & \\
\hline Non-respondents & 890 & \\
\hline Could not be located & 670 & $\begin{array}{l}\text { Effort to relocate respondents focused in states of } \\
\text { residence in } 1989\end{array}$ \\
\hline Refusal & 103 & \\
\hline Not at home & 48 & \\
\hline Left U.S. temporarily & 23 & \\
\hline Too ill to interview & 17 & \\
\hline Moved too far, no phone & 16 & \\
\hline Postal problem & 8 & \\
\hline Language problem & 5 & \\
\hline
\end{tabular}


Table A2

Variables Description

\section{Legalized Population Survey}

Fraction remitting

Dollar remitted

Year 1991

Male

Age

State of residence Undocumented at last entry Years in the U.S.

Family income
Education

$=1$ if respondent (and her family) sent money to family and friends in other countries; 0 otherwise.

Amount of money sent to family and friends excluding zeros and in 1991 dollars (adjusting for inflation using consumer price index).

$=1$ for year 1991 (post legalization period); 0 otherwise.

$=1$ if respondent is male; 0 otherwise.

age of the respondent $(16+)$. Linear and quadratic terms included.

Four dummy variables indicating highest grade completed: at most $5^{\text {th }}$ grade, between $6^{\text {th }}$ and $11^{\text {th }}$ grade, $12^{\text {th }}$ grade or a high school diploma, at least some college education.

$=1$ if respondent lives in California; 0 otherwise.

$=1$ if respondent entered the U.S without documents; 0 if overstayed his visa. Number of years since the respondent first entered the United States and stayed longer than 3 days. Linear and quadratic terms included.

Nine dummy variables indicating total family income from all sources and from all family members living in the United States in the same household as the respondent: less than $\$ 3,000$; $\$ 3,000-\$ 5,999 ; \$ 6,000-\$ 8,999 ; \$ 9,000-\$ 11,999$; \$12,000-\$14,999; \$15,000-\$19,999; \$20,000-\$24,999; \$25,000-\$29,999; $\$ 30,000$ or more.

Employed $=1$ if the respondent worked during the year; 0 otherwise.

Spouse in the U.S. Spouse abroad Children in the U.S. Parents in the U.S. $=1$ if the respondent is married and the spouse lives in the U.S.; 0 otherwise. $=1$ if the respondent is married and the spouse lives abroad; 0 otherwise. Number of children living in the United States.

$=1$ if the any of the respondent's parents (or the spouse's parents) live in the same household in the United States.

Siblings in the U.S.
$=1$ if the any of the respondent's siblings (or the spouse's siblings) live in the same household in the United States.

\section{Economic Indicators}

U.S. state unemployment rate Origin Country:

Annual GDP per capita growth

Average unemployment rate
Source: Bureau of Labor Statistics

Source: World Development Indicators (The World Bank)

Current and lagged: in 1987 and 1991 or 1986 and 1990, respectively Three-year average centered in 1987 and 1991 (a)

Notes: (a) For some countries figures on unemployment rates are not available for 1987 and 1991, but are available for either (or both) the previous or the following year. To avoid losing observations, we construct three-year averages — when necessary defined using whatever years are available. 
Table A3

Before-After Estimates of the Effects of Legalization on the Propensity to Remit (Sample of migrants whose Spouse Resided in the United States in 1987)

\begin{tabular}{lccccc}
\hline \hline & $\mathbf{( 1 )}$ & $\mathbf{( 2 )}$ & $\mathbf{( 3 )}$ & $\mathbf{( 4 )}$ & $\mathbf{( 5 )}$ \\
\hline Year 1991 & $-0.103^{* * *}$ & $-0.095^{* * *}$ & $-0.052^{* * *}$ & -0.032 & $-0.038^{*}$ \\
& $(0.015)$ & $(0.015)$ & $(0.018)$ & $(0.020)$ & $(0.021)$ \\
Male & $0.086^{* * *}$ & $0.092^{* * *}$ & $0.100^{* * *}$ & $0.100^{* * *}$ & 0.027 \\
& $(0.020)$ & $(0.020)$ & $(0.020)$ & $(0.020)$ & $(0.021)$ \\
Age & $0.019^{* * *}$ & $0.014^{* *}$ & $0.024^{* * *}$ & $0.023^{* * *}$ & $0.021^{* * *}$ \\
& $(0.006)$ & $(0.006)$ & $(0.007)$ & $(0.007)$ & $(0.007)$ \\
Age squared & $-0.027^{* * *}$ & $-0.022^{* * *}$ & $-0.031^{* * *}$ & $-0.031^{* * *}$ & $-0.029^{* * *}$ \\
& $(0.008)$ & $(0.008)$ & $(0.008)$ & $(0.008)$ & $(0.009)$ \\
Undocumented at entry & $0.121^{* * *}$ & $0.102^{* * *}$ & $0.089^{* * *}$ & $0.089^{* * *}$ & $0.080^{* * *}$ \\
& $(0.029)$ & $(0.031)$ & $(0.031)$ & $(0.031)$ & $(0.031)$ \\
At most 5 ${ }^{\text {th }}$ grade & 0.026 & $0.083^{* *}$ & $0.083^{* *}$ & $0.082^{* *}$ & $0.164^{* * *}$ \\
& $(0.038)$ & $(0.040)$ & $(0.040)$ & $(0.040)$ & $(0.041)$ \\
$6^{\text {th }}{ }^{\text {-11 }}{ }^{\text {th }}$ grade & 0.001 & 0.038 & 0.037 & 0.035 & $0.103^{* * *}$ \\
& $(0.036)$ & $(0.037)$ & $(0.036)$ & $(0.036)$ & $(0.038)$ \\
$12^{\text {th }}$ grade/ HS diploma & 0.029 & 0.033 & 0.029 & 0.027 & $0.067 *$ \\
& $(0.040)$ & $(0.039)$ & $(0.038)$ & $(0.038)$ & $(0.040)$ \\
Years in U.S. & & & $-0.024^{* * *}$ & $-0.024^{* * *}$ & $-0.031^{* * *}$ \\
& & & $(0.007)$ & $(0.007)$ & $(0.007)$ \\
Years in U.S. squared & & & $0.000^{* *}$ & $0.000^{* *}$ & $0.001^{* * *}$ \\
& & & $(0.000)$ & $(0.000)$ & $(0.000)$ \\
U.S.-State Unemployment Rate (\%) & & & & $-0.019^{* *}$ & -0.013 \\
& & & & $(0.009)$ & $(0.009)$ \\
U.S. State FE & NO & YES & YES & YES & YES \\
Origin-country FE & NO & YES & YES & YES & YES \\
Individual economic variables & NO & NO & NO & NO & YES \\
\hline \hline
\end{tabular}

Notes: Pooled OLS weighted estimates. Regressions include a constant term. Standard errors (in parentheses) account for correlation across observations for the same individual. ${ }^{*}$ significant at 10 percent, ${ }^{* *}$ significant at 5 percent, *** significant at 1 percent. Sample: LPS balanced panel of 3,760 married individuals at least 16 years old who remitted money home both in 1987 and in 1991, and whose spouse was residing in the United States in 1987. 
Table A4

Before-After Estimates of the Effects of the Log of the Amount Remitted (Sample of Continuous Remitters)

\begin{tabular}{|c|c|c|c|c|c|}
\hline Model Specification & (1) & (2) & (3) & (4) & (5) \\
\hline \multicolumn{6}{|l|}{ A. Homogenous Effects } \\
\hline Year 1991 & $\begin{array}{l}-0.333^{* * *} \\
(0.039)\end{array}$ & $\begin{array}{c}-0.333^{* * *} \\
(0.039)\end{array}$ & $\begin{array}{c}-0.246^{* * *} \\
(0.052)\end{array}$ & $\begin{array}{l}-0.261^{* * *} \\
(0.059)\end{array}$ & $\begin{array}{c}-0.295 * * * \\
(0.061)\end{array}$ \\
\hline Male & $\begin{array}{l}0.467^{* * *} \\
(0.053)\end{array}$ & $\begin{array}{c}0.469 * * * \\
(0.054)\end{array}$ & $\begin{array}{c}0.476^{* * *} \\
(0.054)\end{array}$ & $\begin{array}{l}0.476^{* * *} \\
(0.054)\end{array}$ & $\begin{array}{c}0.365^{* * *} \\
(0.058)\end{array}$ \\
\hline Age & $\begin{array}{l}-0.004 \\
(0.015)\end{array}$ & $\begin{array}{l}-0.008 \\
(0.015)\end{array}$ & $\begin{array}{c}0.009 \\
(0.016)\end{array}$ & $\begin{array}{c}0.009 \\
(0.016)\end{array}$ & $\begin{array}{l}-0.004 \\
(0.016)\end{array}$ \\
\hline Age squared & $\begin{array}{c}0.005 \\
(0.019)\end{array}$ & $\begin{array}{c}0.010 \\
(0.019)\end{array}$ & $\begin{array}{l}-0.007 \\
(0.020)\end{array}$ & $\begin{array}{l}-0.007 \\
(0.020)\end{array}$ & $\begin{array}{c}0.013 \\
(0.020)\end{array}$ \\
\hline Undocumented at entry & $\begin{array}{c}0.124 \\
(0.083)\end{array}$ & $\begin{array}{c}0.059 \\
(0.092)\end{array}$ & $\begin{array}{c}0.030 \\
(0.095)\end{array}$ & $\begin{array}{c}0.031 \\
(0.095)\end{array}$ & $\begin{array}{c}0.082 \\
(0.096)\end{array}$ \\
\hline At most $5^{\text {th }}$ grade & $\begin{array}{l}-0.170 * \\
(0.102)\end{array}$ & $\begin{array}{l}-0.213^{* *} \\
(0.108)\end{array}$ & $\begin{array}{l}-0.209 * \\
(0.108)\end{array}$ & $\begin{array}{l}-0.208^{*} \\
(0.108)\end{array}$ & $\begin{array}{l}-0.060 \\
(0.108)\end{array}$ \\
\hline $6^{\text {th }}-11^{\text {th }}$ grade & $\begin{array}{c}0.030 \\
(0.094)\end{array}$ & $\begin{array}{l}-0.011 \\
(0.098)\end{array}$ & $\begin{array}{l}-0.015 \\
(0.097)\end{array}$ & $\begin{array}{l}-0.015 \\
(0.097)\end{array}$ & $\begin{array}{c}0.091 \\
(0.097)\end{array}$ \\
\hline $12^{\text {th }}$ grade/ HS diploma & $\begin{array}{l}-0.031 \\
(0.103)\end{array}$ & $\begin{array}{l}-0.045 \\
(0.105)\end{array}$ & $\begin{array}{l}-0.057 \\
(0.104)\end{array}$ & $\begin{array}{l}-0.055 \\
(0.104)\end{array}$ & $\begin{array}{l}-0.008 \\
(0.104)\end{array}$ \\
\hline Years in U.S. & & & $\begin{array}{c}-0.052 * * \\
(0.022)\end{array}$ & $\begin{array}{l}-0.052^{* *} \\
(0.022)\end{array}$ & $\begin{array}{c}-0.084 * * * \\
(0.024)\end{array}$ \\
\hline Years in U.S. squared & & & $\begin{array}{c}0.001 * \\
(0.001)\end{array}$ & $\begin{array}{c}0.001^{*} \\
(0.001)\end{array}$ & $\begin{array}{l}0.002 * * \\
(0.001)\end{array}$ \\
\hline U.S.-State Unemployment Rate (\%) & & & & $\begin{array}{c}0.015 \\
(0.022)\end{array}$ & $\begin{array}{c}0.015 \\
(0.023)\end{array}$ \\
\hline U.S. State FE & NO & YES & YES & YES & YES \\
\hline Origin-country FE & NO & YES & YES & YES & YES \\
\hline Individual economic variables & NO & NO & NO & $\mathrm{NO}$ & YES \\
\hline \multicolumn{6}{|l|}{ B. Heterogeneous Effects } \\
\hline Year $1991 *$ Mexico & $\begin{array}{l}-0.310 * * * \\
(0.064)\end{array}$ & $\begin{array}{c}-0.321^{* * *} \\
(0.077)\end{array}$ & $\begin{array}{l}-0.153 \\
(0.122)\end{array}$ & $\begin{array}{l}-0.292^{* * *} \\
(0.065)\end{array}$ & $\begin{array}{c}-0.368 * * * \\
(0.082)\end{array}$ \\
\hline Year $1991 *$ other Latin America & $\begin{array}{l}-0.093 \\
(0.071)\end{array}$ & $\begin{array}{l}-0.092 \\
(0.071)\end{array}$ & $\begin{array}{l}-0.070 \\
(0.075)\end{array}$ & $\begin{array}{l}-0.117^{*} \\
(0.071)\end{array}$ & $\begin{array}{l}-0.123^{*} \\
(0.071)\end{array}$ \\
\hline U.S. State Unemployment Rate (\%) & $\begin{array}{c}0.005 \\
(0.022)\end{array}$ & $\begin{array}{c}0.005 \\
(0.022)\end{array}$ & $\begin{array}{c}0.004 \\
(0.022)\end{array}$ & $\begin{array}{c}0.003 \\
(0.023)\end{array}$ & $\begin{array}{c}0.002 \\
(0.023)\end{array}$ \\
\hline $\begin{array}{l}\text { Origin country annual GDP } \\
\qquad \text { per capita growth }\end{array}$ & & $\begin{array}{l}8.368 * * * \\
(0.394)\end{array}$ & & & $\begin{array}{c}0.031 \\
(0.021)\end{array}$ \\
\hline $\begin{array}{l}\text { Origin country annual GDP } \\
\text { per capita growth (lagged) }\end{array}$ & & & $\begin{array}{l}-0.018 \\
(0.012)\end{array}$ & & \\
\hline $\begin{array}{l}\text { Origin country three-years } \\
\text { Average Unemployment rate (\%) }\end{array}$ & & & & $\begin{array}{l}-0.018 \\
(0.014)\end{array}$ & $\begin{array}{l}-0.016 \\
(0.014)\end{array}$ \\
\hline U.S. State FE & NO & YES & YES & YES & YES \\
\hline Origin-country FE & NO & YES & YES & YES & YES \\
\hline
\end{tabular}

Notes: Pooled OLS weighted estimates. Regressions include a constant term. Standard errors (in parentheses) account for correlation across observations for the same individual. * significant at 10 percent, ** significant at 5 percent, *** significant at 1 percent. Sample: LPS balanced panel of 2,971 individuals at least 16 years old who remitted money home both in 1987 and in 1991. 